\title{
Imprinting disorders: a group of congenital disorders with overlapping patterns of molecular changes affecting imprinted loci
}

\author{
Thomas Eggermann 1,13,14*, Guiomar Perez de Nanclares², Eamonn R. Maher ${ }^{3}$, I. Karen Temple ${ }^{4,5}$, Zeynep Tümer ${ }^{6}$, \\ David Monk ${ }^{7}$, Deborah J. G. Mackay ${ }^{4,5}$, Karen Grønskov ${ }^{6}$, Andrea Riccio ${ }^{8}$, Agnès Linglart ${ }^{9}$ and Irène Netchine ${ }^{10,11,12}$
}

\begin{abstract}
Congenital imprinting disorders (IDs) are characterised by molecular changes affecting imprinted chromosomal regions and genes, i.e. genes that are expressed in a parent-of-origin specific manner. Recent years have seen a great expansion in the range of alterations in regulation, dosage or DNA sequence shown to disturb imprinted gene expression, and the correspondingly broad range of resultant clinical syndromes. At the same time, however, it has become clear that this diversity of IDs has common underlying principles, not only in shared molecular mechanisms, but also in interrelated clinical impacts upon growth, development and metabolism. Thus, detailed and systematic analysis of IDs can not only identify unifying principles of molecular epigenetics in health and disease, but also support personalisation of diagnosis and management for individual patients and families.
\end{abstract}

Keywords: Imprinting disorders, Imprinted genes, Epimutation, Uniparental disomy

\section{Background}

Imprinting disorders (IDs) are a group of congenital diseases characterised by overlapping clinical features affecting growth, development and metabolism, and common molecular disturbances, affecting genomically imprinted chromosomal regions and genes. The term genomic imprinting describes the expression of specific genes in a parent-of-origin specific manner - i.e. they are expressed only from the maternal or from the paternal gene copy, but not biparentally. Disturbances of imprinted genes may alter their regulation ("epigenetic mutation") and dosage and rarely their genomic sequences can be altered ("genetic mutation").

So far, more than 150 human genes have been shown to be imprinted (for review, http://www.geneimprint.$\mathrm{com} /$ site/genes-by-species), but it is likely that more remain to be identified. Imprinting marks, like other epigenetic marks, are re-established at each generation

\footnotetext{
* Correspondence: teggermann@ukaachen.de

'Department of Human Genetics, RWTH Aachen, Pauwelsstr. 30, Aachen, Germany

${ }^{13}$ Sorbonne Universites, UPMC Univ Paris 06, UMR_S 938, CDR Saint-Antoine, Paris, France

Full list of author information is available at the end of the article
}

by successive removal and re-establishment in the germ cell lineages, and then in early zygotic development. The critical difference between imprinting marks and all others is that they elude postzygotic reprogramming, and therefore are essentially ubiquitous and permanent in somatic tissues - except for the germline lineage that embarks upon the establishment of the subsequent generation (for review, [1]).

Imprinted loci often comprise multiple genes under coordinated epigenetic control (Figs. 1, 2, 3, 4, 5, 6, 7, 8 and 9). This control includes four interacting molecular components: DNA methylation, post-translational histone modification, chromatin structure and non-coding RNAs. The intricate interactions of these regulatory mechanisms across development lead to a stage- and tissue-specific transcriptional activity in cells with identical DNA sequences.

In IDs, the regulation of imprinted genes and imprinting clusters are disturbed by different changes. In the majority of ID patients only the disease-specific loci are affected, but an increasing number of individuals have been shown to have disturbed methylation at multiple imprinted loci, the so-called multilocus methylation imprinting disturbances (MLID). Another extreme example 


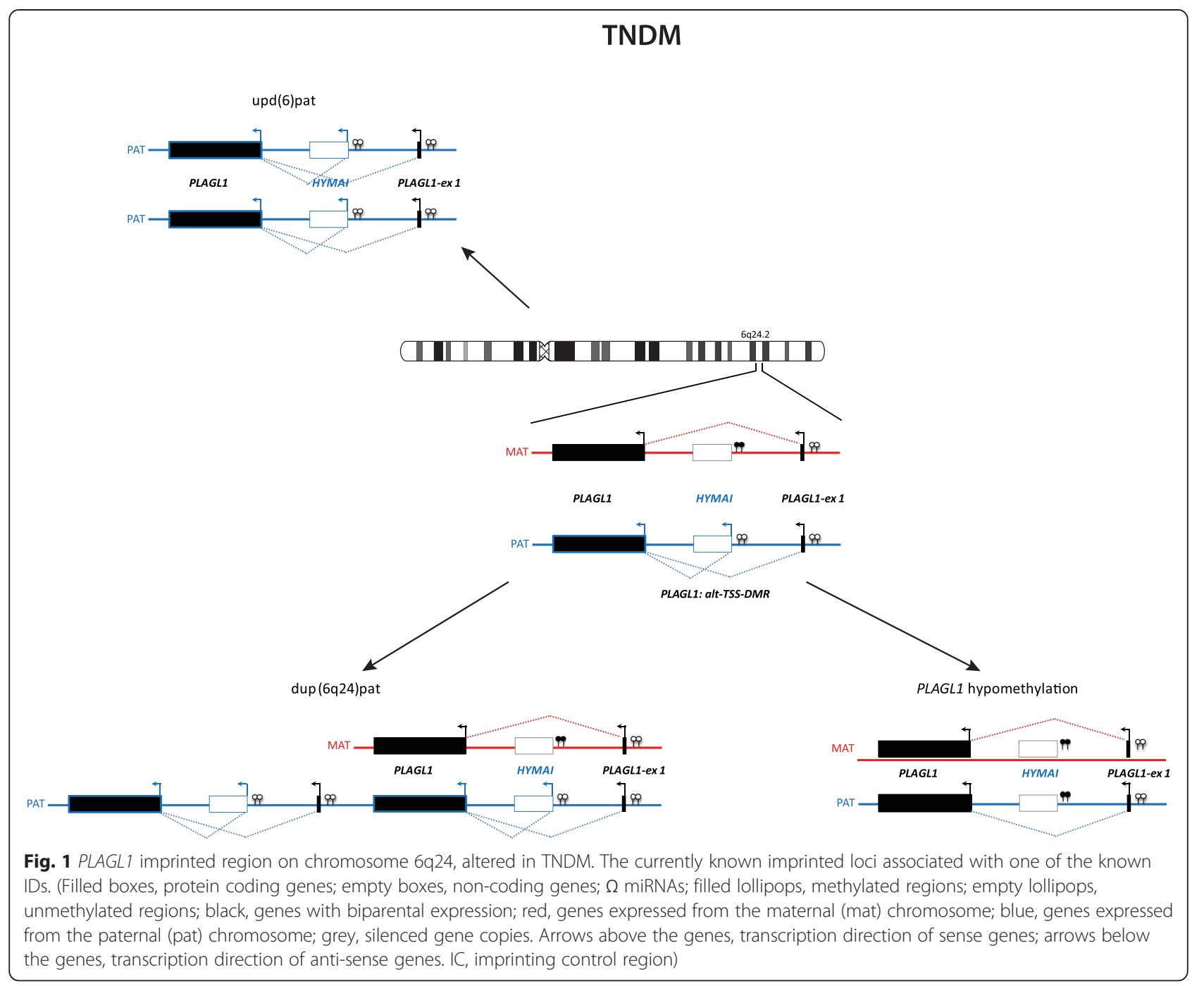

of unbalanced imprinting patterns is uniparental diploidy (e.g. complete hydatidiform moles, where all the chromosomes are of paternal origin) or triploidies (e.g. partial hydatidiform moles where an extra haploid set of chromosomes of either maternal or paternal origin is present). These cases are not viable. However, mosaic genomewide uniparental isodiploidy has been reported to be compatible with life (for review, [2]).

\section{Types of mutations and epimutations in IDs}

In the majority of the well established IDs, the same four classes of molecular changes have been reported (Table 1, Figs. 1, 2, 3, 4, 5, 6, 7, 8 and 9): uniparental disomy (UPD), chromosomal imbalances, aberrant methylation (epimutation) and genomic mutations in imprinted genes. The functional result in each case is the unbalanced expression of imprinted genes, but the phenotypic outcome depends on the parental allele affected by the mutation.
Since the genetic counseling for each ID is affected by both its familial inheritance and its underlying pathogenetic mechanism, precise molecular diagnosis is essential for accurate management and reproductive counseling. Furthermore, in some IDs somatic and germline mosaicism have been reported, a finding which may be difficult to diagnose, but must be considered since it may compromise molecular genetic testing.

\section{Uniparental Disomy (UPD)}

UPD is the inheritance of both chromosomal homologues from the same parent and has been reported for nearly all IDs (Table 1; for review, [3]). The recurrence risk for another child with UPD is generally low with the exception of those UPDs affecting acrocentric chromosomes (chromosomes 14 and 15): these chromosomes are prone to Robertsonian translocations (RT) which predispose to non-disjunctional errors and thus a UPD formation. However, the risk to have a child with UPD is 


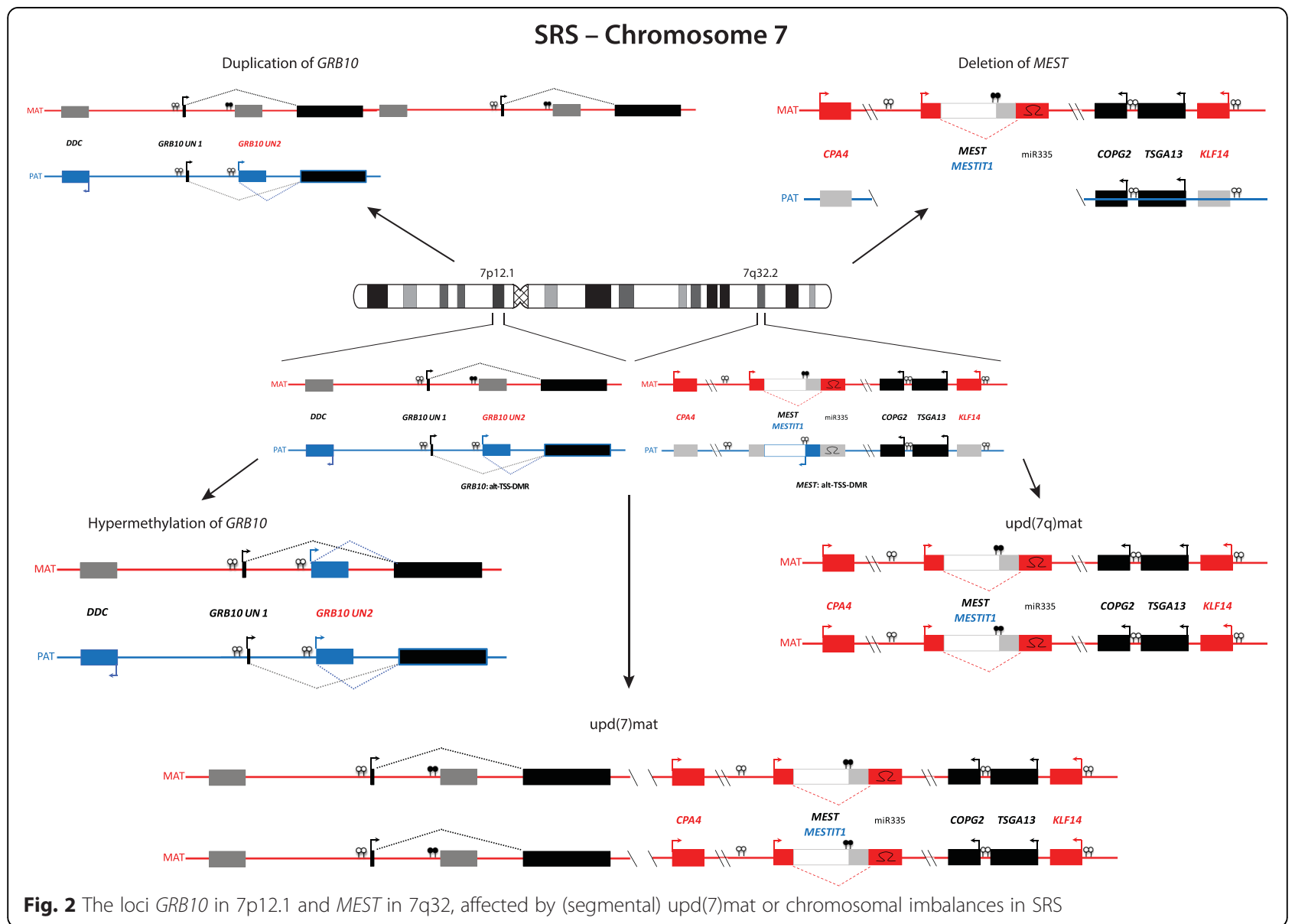

below $1 \%$, but prenatal testing for UPD is recommended in carriers of balanced translocations affecting chromosomes carrying imprinted genes [4].

\section{Chromosomal rearrangements (deletions, duplications, translocations)}

Chromosomal imbalances either cause a loss of a gene and thereby a loss of expression of an imprinted gene in case of deletions or translocations or they result in an overexpression by duplication of imprinted chromosomal material. However, due to the complex regulation mechanisms in imprinted regions, loss of chromosomal material can also indirectly cause an overexpression of an imprinted gene due to the removal of a negative cisacting element and vice versa (e.g. [5-7]).

In some IDs, deletions account for the majority of cases, e.g. in Angelman syndrome (AS) and PraderWilli syndrome (PWS). They can either occur de novo, or they can be caused by inherited chromosomal rearrangements (e.g. RT). In case of familial cases, the parent-of-origin-dependent gene expression results in autosomal-dominant inheritance with a parent-oforigin-dependant penetrance.

\section{Intragenic mutations in imprinted genes}

So far, genomic point mutations in imprinted genes have only been reported for Beckwith-Wiedemann syndrome (BWS), Silver-Russell syndrome (SRS), AS, precocious puberty and pseudohypoparathyoridism (PHP) (Table 1). In precocious puberty syndrome (central precocious puberty 2; cppb2), MKRN3 mutations are the only causative molecular alterations known so far. In the other IDs, their significance differs: AS mutations in the $U B E 3 A$ contribute to $10-15 \%$ of cases, and approximately $30 \%$ are inherited. In PHP, mutations on the coding maternal allele of GNAS are responsible for $70 \%$ of type $1 \mathrm{~A}$ disease ( $50 \%$ of total PHP), whereas, deletions of genomic regulatory regions have been identified in $20-30 \%$ of the $1 \mathrm{~B}$ subtype $(\sim 8.5 \%$ of total PHP) [8]. In BWS, inhibiting CDKN1C mutations can be detected, in SRS, only one case with an activating CDKN1C mutation has been reported so far [9]. To further determine the recurrence risk in the families of these patients, familial segregation studies should be offered to establish the maternal/paternal inheritance or lack thereof, even when parents do not show obvious clinical features. 


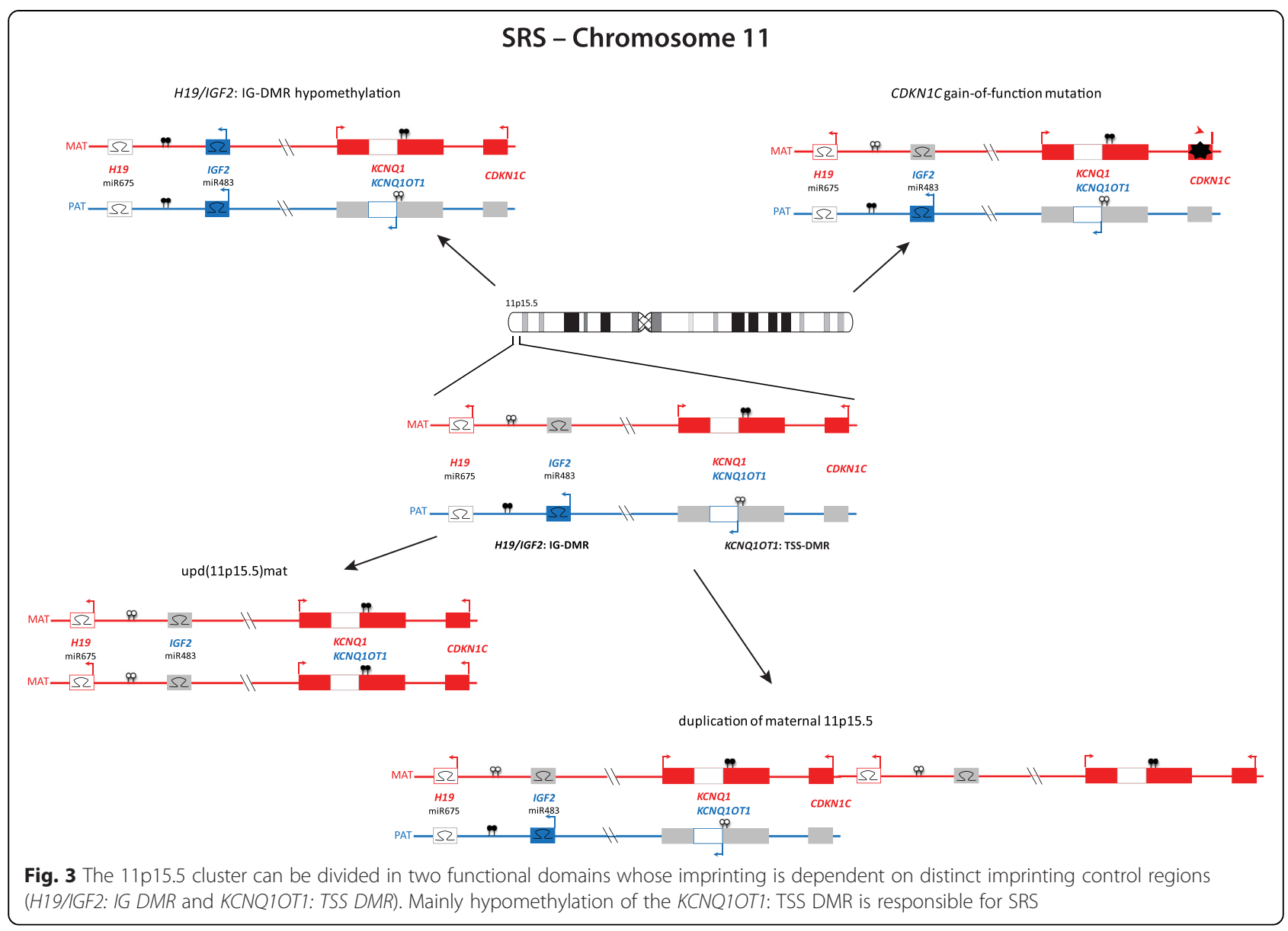

\section{Epimutations}

Epimutations aberrant methylation of a differentially methylated region (DMR) without alteration of the same genomic DNA sequence account for up to $50 \%$ of molecular changes in IDs (Table 1). To contribute to the full clinical picture of an ID, hypo- or hypermethylation should affect the disease-specific germ-line DMR (e.g. the H19-DMR in 11p15), but in several IDs the methylation at further DMRs (e.g. IGF2-DMRs in 11p15) is altered [10] and might influence the severity of an ID (e.g. Kagami-Ogata syndrome/KOS14, [11]). Epimutation can occur as a result of a DNA mutation in a cis- or trans-acting factor ("secondary epimutation"), or as a primary epimutation in the absence of any DNA sequence change ("primary epimutation"). Primary epimutations often occur after fertilization and lead to somatic mosaicism. It has been estimated that the rate of primary epimutations is 1 or 2 orders of magnitude greater than somatic DNA mutations [12] and is associated with assisted reproductive technology [13], in keeping with environmental disturbances.

In terms of molecular mechanism, the four causes of IDs can interact: chromosomal translocations can predispose to both imbalances and UPD, and deletions or point mutations in regulatory domains can affect the imprinting status of a DMR $[6,10,14]$. It is noteworthy that some molecular changes may occur postzygotically, resulting in a mosaic distribution. Mosaicism can obscure genotype-phenotype correlation and is also associated with somatic asymmetry; and discordant monozygotic twinning, which can be regarded as an extreme expression of epigenetic asymmetry, is a common feature in IDs (for review, [15]). It may also render difficult the molecular diagnosis if the analysed tissue is not or poorly epigenetically modified.

\section{Clinical and molecular findings in Imprinting Disorders}

With the exception of the precocious puberty syndrome, the clinical features of IDs are present at birth and in early childhood. Indeed, some of them can be identified prenatally. Each ID is characterised by specific clinical features, and they have been regarded as separate entities. However, the majority of IDs share clinical (and molecular) characteristics (Tables 1 and 2), and in nearly all of them growth, metabolism and/or development are affected. Furthermore, they share several sequelae (e.g. diabetes; Table 2). In several disorders, the symptoms 


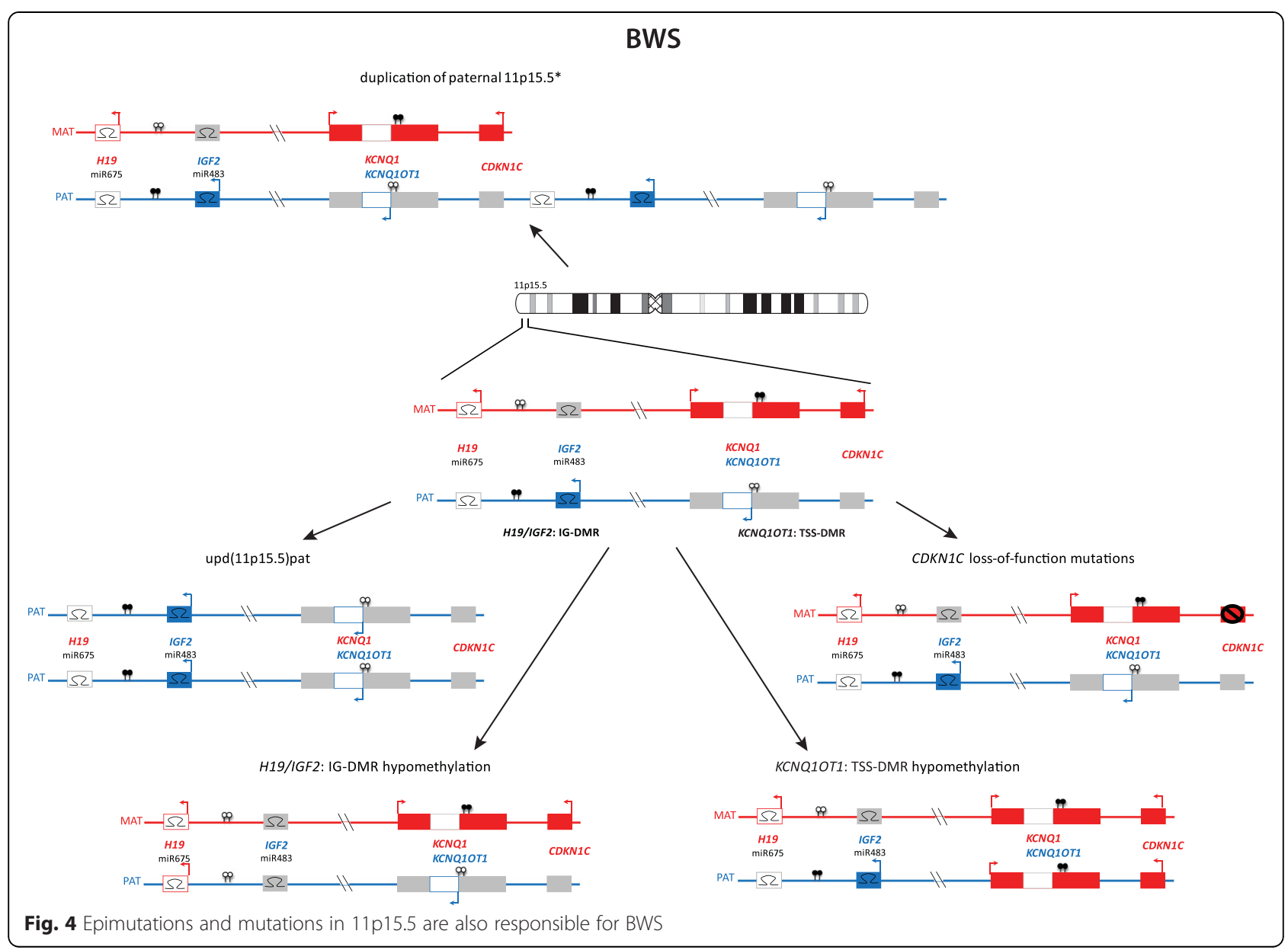

are subtle, unspecific and transient; therefore, some IDs are probably mis- and underdiagnosed.

Currently, nine IDs have been described, but there are certainly more: In addition to the generally accepted paediatric IDs and the specific precocious puberty entity, there are three further molecular disturbances in discussion to represent separate IDs (upd(6)mat, upd(16)mat, upd(20)mat).

\section{Transient neonatal diabetes mellitus type 1}

Transient neonatal diabetes mellitus type type 1 (TNDM1) is characterised by intrauterine growth retardation (IUGR) and hyperglycaemia in infancy. The diabetes mellitus typically develops in the first weeks of life and resolves by the age of 18 months; however, it is growing clear that individuals with TNDM are at risk of relapse, in adolescence or early adulthood, with type 2 diabetes $[16,17]$. Aside from these features, TNDM1 has no major cardinal features; however, individuals may have congenital abnormalities [18]. Macroglossia (large tongue) affects just under half of infants with TNDM1, and about one in five individuals may also have a minor anomaly of the abdominal wall. Other congenital problems are rare and may be associated with MLID rather than TNDM per se. Approximately $10 \%$ of individuals with TNDM1 do not present with hyperglycaemia at birth [19].

TNDM is associated with an overexpression of PLAGL1/ZAC in 6q24 (Fig. 1), a maternally imprinted gene. It encodes a zinc finger protein which binds DNA and hence influences the expression of other genes (for review, [20].

\section{Silver-Russell syndrome}

SRS is a clinically and molecularly heterogeneous growth retardation syndrome. Apart from pre- and postnatal growth failure, the major features include a relative macrocephaly at birth, a typical facial gestalt (protruding forehead, triangular face), body asymmetry, and feeding difficulties in infancy. Furthermore, first follow-up data indicate a risk for adult-onset diseases [21]. The clinical presentation is variable and at least in part influenced by the mosaic distribution of molecular changes [22], but several scoring systems have been suggested [23]. Approximately $10 \%$ of SRS patients have maternal UPD for chromosome 7 (upd(7)mat) or segmental upd(7q)mat 


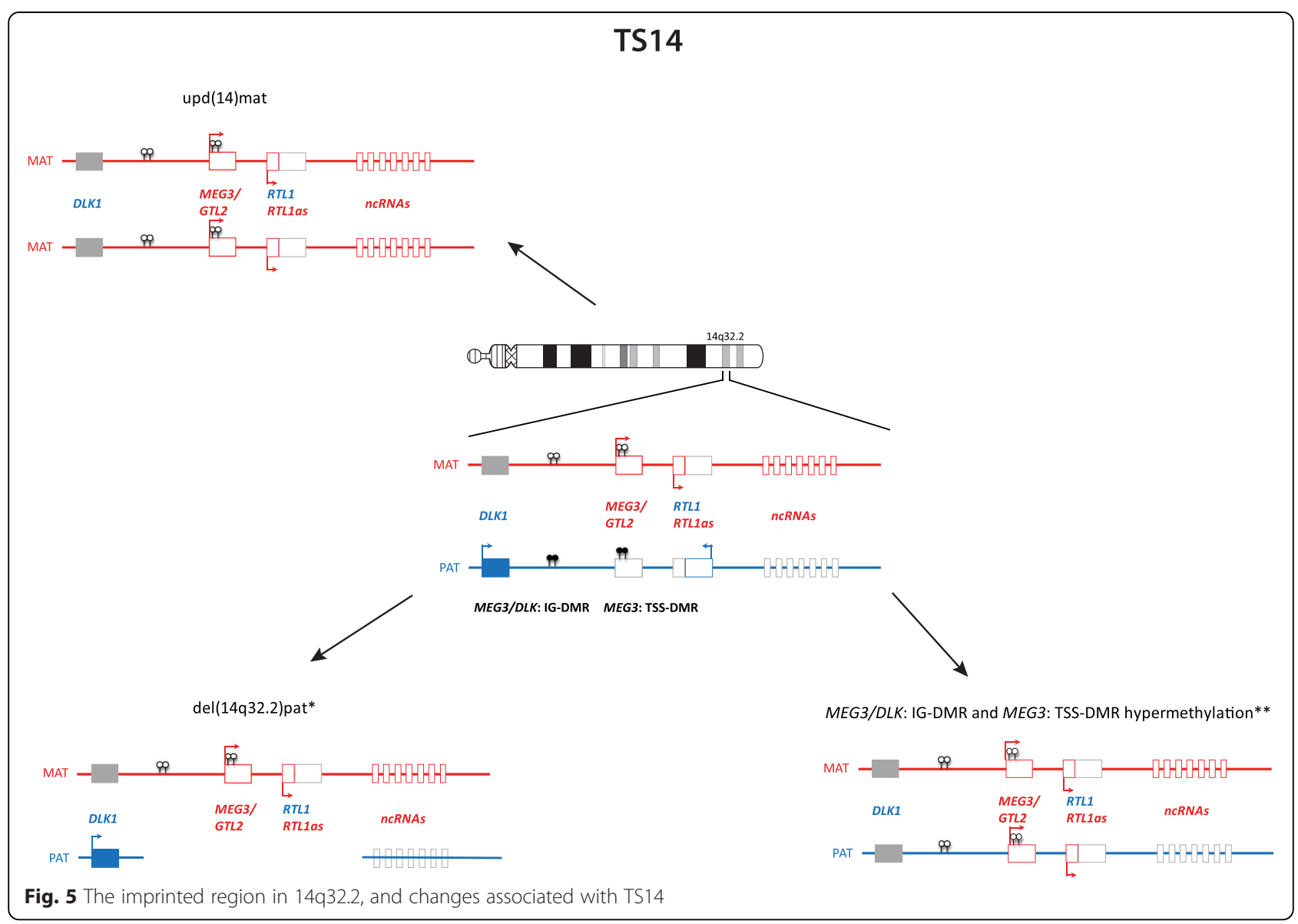

(for review, [24, 25]) (Fig. 2). The majority of patients carry molecular changes in $11 \mathrm{p} 15$, the most prevalent ( 40 \%) being hypomethylation of H19/IGF2: IG DMR (Fig. 3). Additionally, numerous (submicroscopic) disturbances of chromosomes 7 and 11 as well as of other chromosomes have been described; thus screening for cryptic genomic imbalances is indicated after exclusion of upd(7)mat and 11p15 epimutations [26, 27]. The genes causing the SRS phenotype on chromosomes 7 and 11 are currently unknown, but evidences for a role of IGF2 and CDKN1C in 11p15.5 and MEST in 7q32 have been reported $[9,28-30]$.

\section{Beckwith-Wiedemann syndrome}

BWS was initially called EMG syndrome from its three main features of exomphalos, macroglossia and (neonatal) gigantism. The clinical diagnosis of BWS is often difficult due to its variable presentation and the phenotypic overlap with other overgrowth syndromes (for review, [31-33]) and isolated hemihypertrophy. In 5-7 \% of children, embryonal tumours (most commonly Wilms tumour) are diagnosed.

In nearly $80 \%$ of BWS patients chromosome $11 \mathrm{p} 15.5$ epimutations or mutations (Fig. 4), involving multiple loci, can be detected (including the ICR1 and KCNQ1OT1: TSS DMR DMRs)(for review, [34]). Most BWS cases are sporadic but familial inheritance is observed in up to $15 \%$ of all cases. Microdeletions/duplications or point mutations at the ICRs are usually found in familial BWS with aberrant 11p15 methylation; for example, deletions and point mutations of OCT4/SOX4 binding sites in H19/IGF2: IG DMR are associated with H19/IGF2: IG DMR hypermethylation [5, 35, 36]. Conversely, CDKN1C mutations are frequent in familial cases with normal 11p15 methylation [37]. These BWS pedigrees resemble that of an autosomal dominant inheritance but with parent-of-origin dependent effects on penetrance. Most cases of BWS with an KCNQ1OT1: TSS DMR epimutation are sporadic but there is an association with assisted reproductive technologies [38]. Robust genotype/epigenotype-phenotype correlations have been established for BWS [35, 39, 40]: hemihypertrophy is strongly associated with upd(11)pat, exomphalos with KCNQ1OT1: TSS DMR hypomethylation and CDKN1C mutations, and, most importantly, the risk of Wilms tumour is significantly increased in H19/IGF2: IG DMR hypermethylation and upd(11)pat in comparison to the other molecular subgroups. By contrast, other embryonic 


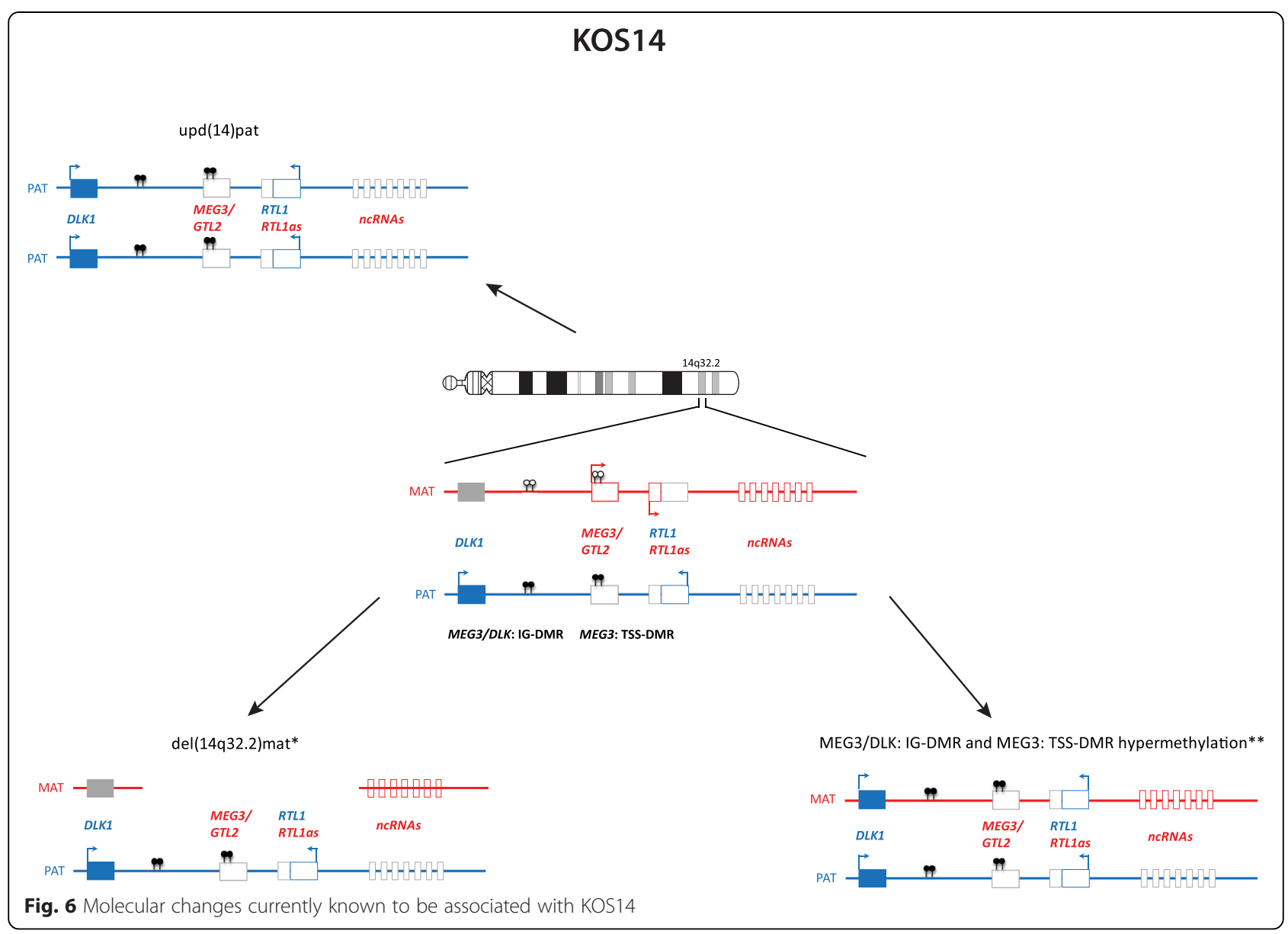

tumors such as neuroblastoma and adrenal tumors are observed in patients with KCNQ1OT1: TSS DMR or upd(11)pat but at a much lower incidence. Hence, the determination of the molecular subtype is important for an individual prognosis and management. Nevertheless, the phenotypic transitions are fluid and testing for all molecular subtypes should be offered in patients with BWS features.

\section{Temple syndrome}

Temple syndrome (TS14) was first described in 1991 in a patient with a maternal UPD of chromosome 14 [41], and after it turned out that it is a recognizable phenotype the name upd(14)mat syndrome was suggested. Meanwhile, other molecular changes have been reported as well $[42,43]$; therefore, the name TS14 has been proposed [44] (Fig. 5). TS14 is mainly characterised by prenatal and postnatal growth retardation, muscular hypotonia, feeding difficulties in early childhood, truncal obesity and early onset of puberty. TS14 patients show clinical features overlapping with PWS and SRS; thus, screening for chromosome 14q32 should be performed in patients with PWS- and SRS-like phenotypes after exclusion of the specific (epi)mutations. For TS14 the role of an altered RTL1 and DLK1 expression has been suggested [42].

\section{Kagami-Ogata syndrome}

The second recently defined ID is KOS14 which is mainly characterised by polyhydramnios, placentomegaly, excessive birth weight, a unique facial appearance with full cheeks and protruding philtrum, distinctive chest roentgenograms with coathanger rips and a bellshaped thorax, abdominal wall defects (omphalocele, diastasis recti), variable developmental delay and/or intellectual disability, poor sucking usually requiring gastric tube feeding, hepatoblastoma and a mortality rate of $20-25 \%$ in the neonate period [45].

Known causes of KOS are upd(14)pat ( 65\%), epimutations affecting the MEG3/DLK: IG DMR and the MEG3: TSS DMR ( 15 \%) and microdeletions involving the MEG3/DLK: IG DMR and/or the MEG3: TSS DMR ( $20 \%$ ) (Fig. 6). The detailed characterisation of KOS14 with deletions of different sizes has allowed the deciphering of the regulation mechanism in the $14 \mathrm{q} 32$ imprinted region [11, 46]: whereas deletion of the 


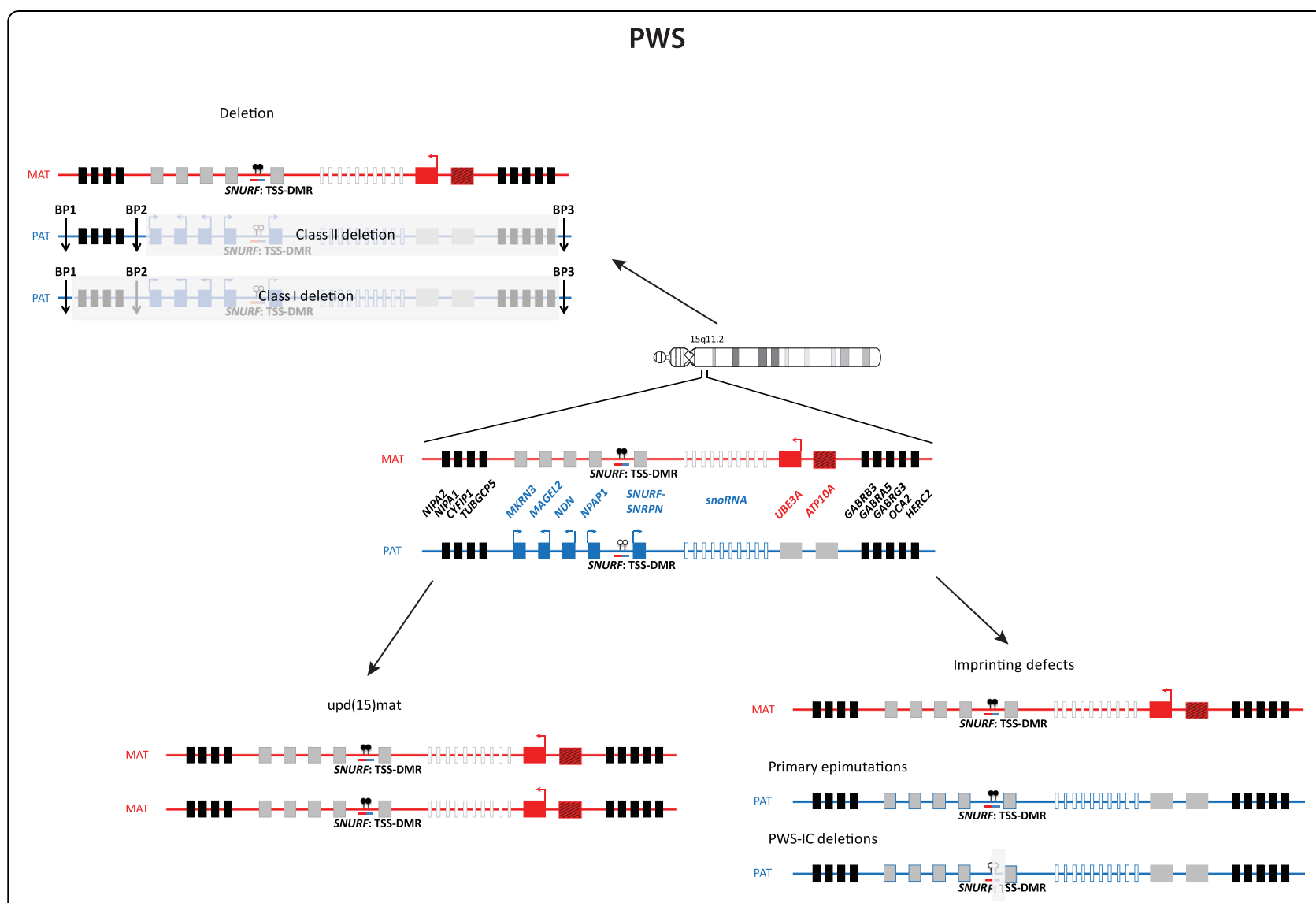

Fig. 7 The imprinted region in 15q11.2 and PWS. UBE3A encodes an E3 ubiquitin-protein ligase which is expressed exclusively from the maternal allele in human fetal brain and in adult frontal cortex. The role of ATP10A is unclear

MEG3/DLK: IG DMR is associated with both the clinical KOS14 phenotype and placental abnormalities, carriers of deletions restricted to the MEG3: TSS DMR do not show placental abnormalities. It has been postulated that the increased expression of RTL1 is responsible for the clinical outcome, whereas a role of DLK1 can be neglected [42].

\section{Angelman syndrome}

A clinical diagnosis of AS demands fulfilment of four major criteria and minimum three of the six minor criteria. The major criteria are severe developmental delay, movement or balance disorder, severe limitations in speech and language and typical abnormal behavior including happy demeanor and excessive laughter. The six minor criteria are postnatal microcephaly, seizures, abnormal EEG, sleep disturbance, attraction to or fascination with water, and drooling [47]. The unique clinical features do not usually manifest within the first year of life, but developmental delay is noticed around 6 months of age. In about $10 \%$ of the individuals with a clinical diagnosis of AS it is not possible to find the underlying genetic mechanism and other diagnoses should be considered. AS can be caused by maternally derived de novo deletion of 15q11-q13 (70-75\%), paternal uniparental disomy (upd(15)pat) of chromosome 15 (3-7 \%) or an imprinting defect (2-3\%) all of which lead to lack of expression of maternally expressed 15q11-q13 genes (Fig. 7). Furthermore, mutations in $U B E 3 A$ also cause Angelman syndrome (10-15\%). Imprinting defects can either be due to primary imprinting epimutations without DNA sequence alterations or due to deletions in the imprinting centre (IC) critical region (AS-SRO) [48, 49]. The 15q11-q13 chromosomal region contains imprinted genes, some of which are exclusively expressed from either of the parental alleles. Two exclusively maternally expressed genes, $U B E 3 A$ and $A T P 10 A$, are located with this region: $U B E 3 A$ encodes an E3 ubiquitin-protein ligase which is expressed exclusively from the maternal allele in human foetal brain and in adult frontal cortex $[50,51]$. AS can be caused either by lack of $U B E 3 A$ expression or by mutations in $U B E 3 A$. The role of the other imprinted gene, $A T P 10 A$, is however unclear. In individuals with deletions, UPD or imprinting defects, ATP10A expression is lacking, but in individuals with point mutations in $U B E 3 A$ it is left unaffected. 


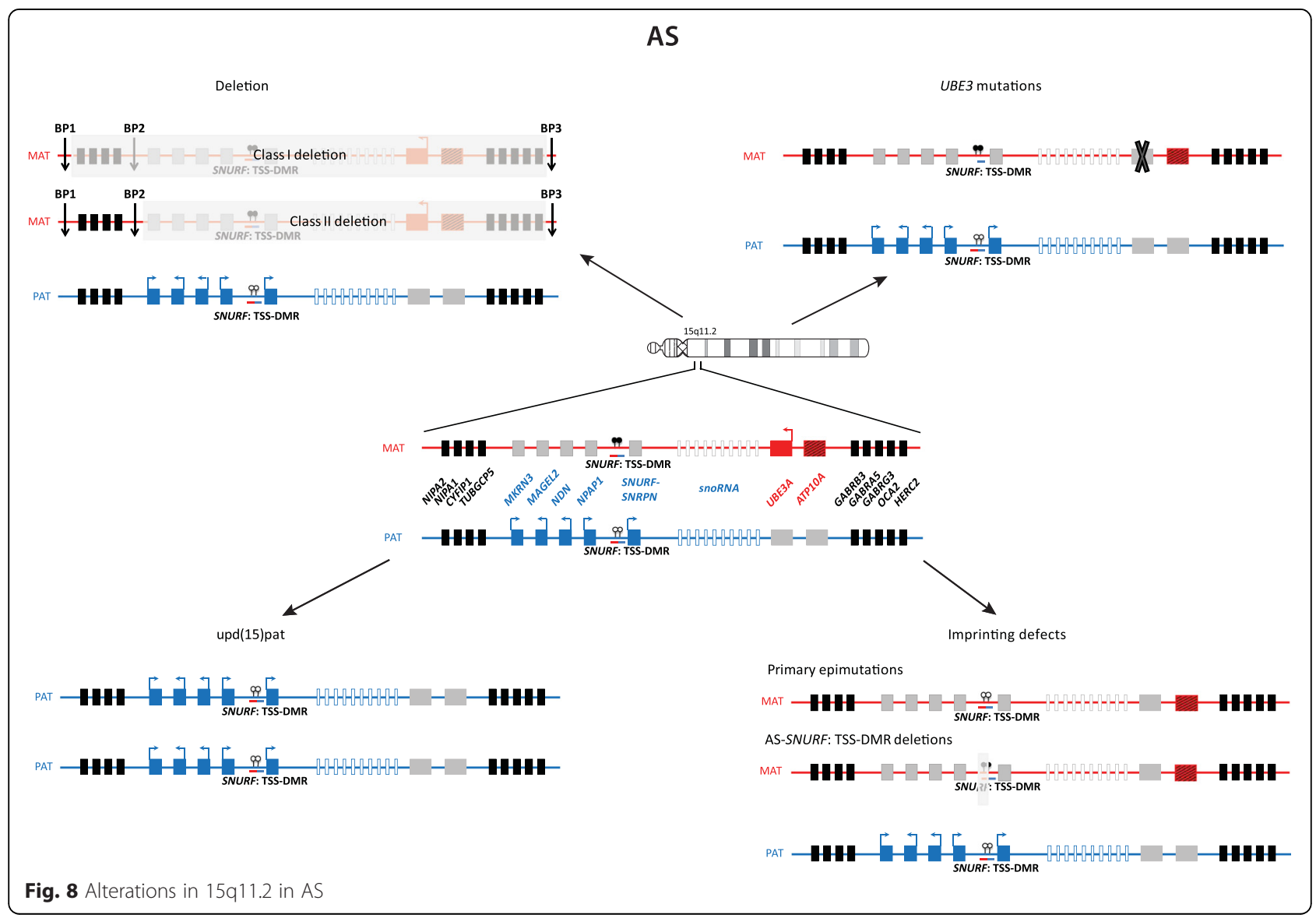

\section{Prader-Willi syndrome}

PWS is clinically characterised by severe hypotonia and feeding difficulties in early infancy, followed by excessive eating and development of morbid obesity in later infancy or early childhood. Cognitive impairment is seen in almost all individuals but varies in severity. A behavioral phenotype with temper tantrums, stubbornness, manipulative behavior and obsessive-compulsive disorder is constant. Hypogonadism in both males and females may cause genital hypoplasia and incomplete pubertal development; and most individuals are infertile. Short stature, and small hands and feet are common features. Characteristic facial features, strabismus and scoliosis are often present. Clinical diagnostic criteria for PWS have been developed [52, 53]; however, confirmation of the clinical diagnosis with molecular genetic testing is required.

PWS is caused by lack of expression of the paternally contributed 15q11-q13 genes. There are three mechanisms leading to PWS: deletion of the 15q11-q13 imprinted loci on the paternal allele (75-80\%), maternal UPD of chromosome 15 (upd(15)mat) (20-25\%) and imprinting defects $(<1 \%)$ (Fig. 8). The common breakpoint for the deletions are the same as for AS. Imprinting defects can either be due to primary epimutations without DNA sequence alterations or it can be due to small deletions in the imprinting centre (IC) critical region (PWS-SRO) [54]. The 15q11-q13 chromosomal region contains imprinted genes, some of which are exclusively expressed from either of the parental alleles. Paternally expressed genes are: MKRN3, MAGEL2, NDN, PWRN1, C15orf2, SNURF-SNRPN and several snoRNA genes (SNORD64, SNORD107, SNORD108, SNORD109A, SNORD109B, SNORD115 and SNORD116). SNORD115 and SNORD116 are present in 47 and 24 gene copies, respectively, whilst the other snoRNA genes are single copy genes. Deficiency of SNORD116 is thought to cause the key characteristics of the PWS phenotype $[55,56]$.

\section{Precocious puberty}

Puberty is a complex biological process involving sexual maturation and accelerated growth. These processes normally initiate when pulsatile secretion of gonadotropinreleasing hormone ( $\mathrm{GnRH})$ from the hypothalamus begins. Early activation of the hypothalamic-pituitary-gonadal axis results in gonadotropin-dependent precocious puberty (also known as central precocious puberty, CPP; development of secondary characteristics before the age of 8 year in girls and 9 years in boys). With the advent of advanced sequencing methods, exome-sequencing of familial cases 


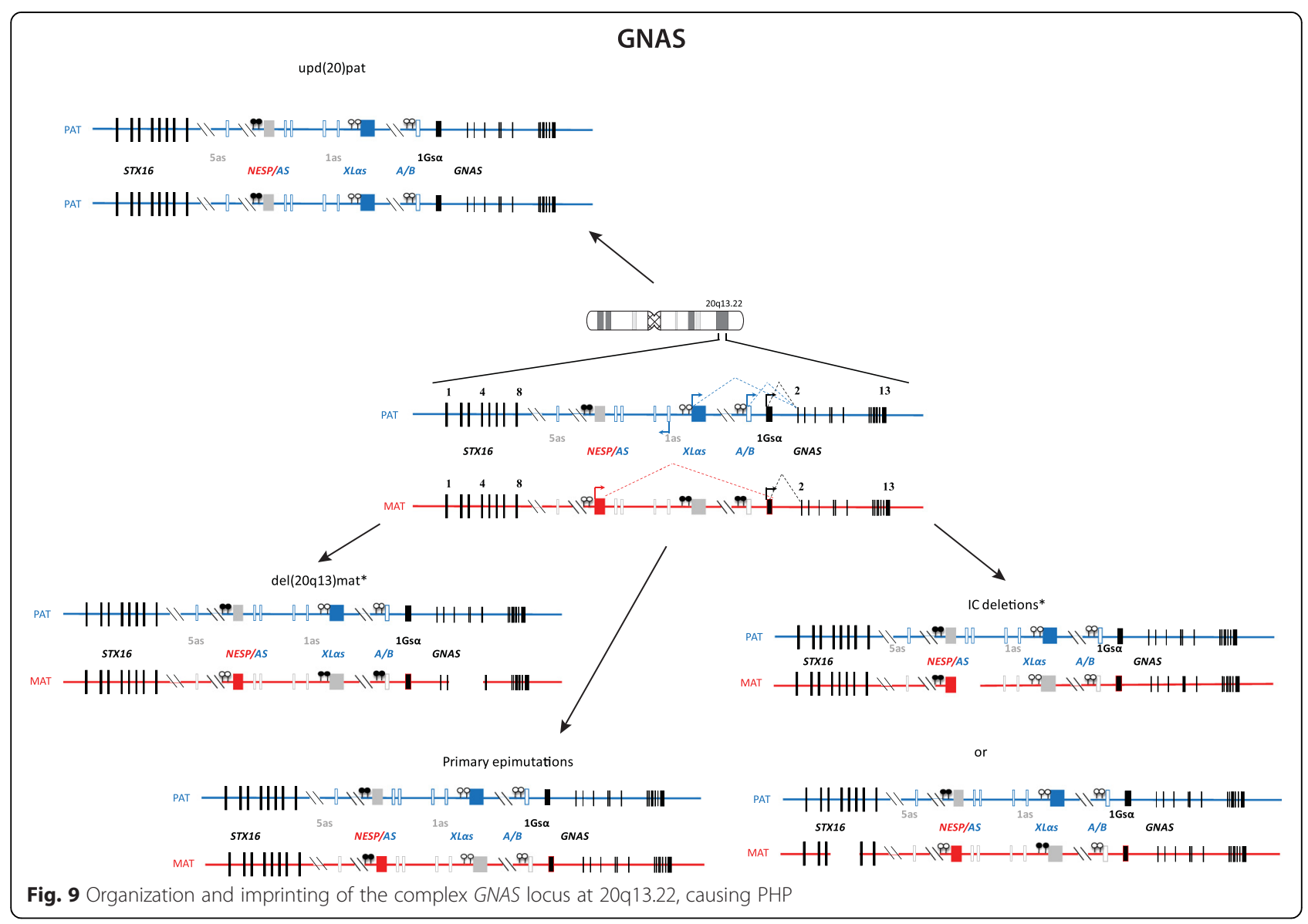

of CPP have identified genetic defects in transcripts with no previous link to hypothalamic-pituitary-gonadal regulation. Loss-of-function mutations in the Makorin ring finger 3 (MKRN3) were initially identified in CPP families [57-60]. Consistent with the genes imprinting status the phenotype was only present upon paternal transmission of the mutation. Subsequently, mutations in $M K R N 3$ have been shown to be the most frequent cause of familial CPP and they have also been detected in nearly $4 \%$ in a cohort of 215 non-familial idiopathic CCP [61]. The MKRN3 gene (also known as ZNF127) is an intronless transcript located on chromosome 15q11.2 in the PWS critical region, encoding for a protein with $\mathrm{C} 3 \mathrm{H}$ zinc-finger and RING zinc-finger motifs. Unlike other imprinting disorders that can result from multiple mechanisms, it is currently unknown if CCP can arise from loss of $M K R N 3$ expression due to deletion, segmental maternal uniparental disomy or an imprinting defect.

\section{Pseudohypoparathyroidism}

PHP is a group of disorders characterised by PTH resistance in the kidney, i.e. pseudohypoparathyroidism. Most cases of PHP belong to the type 1, i.e. are caused by genetic or epigenetic alterations at the imprinted GNAS locus. PHP1A comprises patients affected with resistance to PTH and TSH (and other GPCR proteins), and features of obesity and Albright hereditary osteodystrophy including short stature, brachydactyly, ectopic ossifications and mental retardation. PHP1A is caused by inactivating mutations in the maternal allele of the GNAS gene. Paternal GNAS mutations are associated with AHO, no hormonal resistance and no obesity, a constellation of features grouped under the term of pseudopseudohypoparathyroidism (PPHP) as well as with progressive osseous heteroplasia $(\mathrm{POH})$. In contrast, the phenotype of most PHP1B patients is limited to renal PTH resistance [62] and in some cases, mild TSH resistance. Few patients with PHP1B display some features of Albright hereditary osteodystrophy [63]. Patients with PHP1B share a loss of methylation at the $\mathrm{A} / \mathrm{B}$ differentially methylated region (DMR) of GNAS, likely leading to the downregulated expression of the GNAS-Gs $\alpha$ transcript in imprinted tissues (Fig. 9). Some patients carry additional epigenomic changes along the GNAS locus. About $20 \%$ of PHP1B are inherited and due to deletions of GNAS imprinting control regions. The remaining $80 \%$ are sporadic. A small subset is due to paternal UPD of chromosome 20q, yet the vast majority are still of unknown cause (for review: [64]). Whilst obesity 
Table 1 Overview on the molecular findings in the currently known IDs and their clinical characteristics

\begin{tabular}{|c|c|c|c|c|c|c|c|c|c|}
\hline Imprinting disorder & Prevalence & OMIM & $\begin{array}{l}\text { Chromosomes/ } \\
\text { imprinted regions }\end{array}$ & $\begin{array}{l}\text { Type of mutation/epimutat } \\
\text { frequencies }\end{array}$ & tion and their & MLID & Mosaicism & Recurrence risk & Main clinical features \\
\hline \multirow{3}{*}{$\begin{array}{l}\text { Transient Neonatal } \\
\text { Diabetes Mellitus (TNDM) }\end{array}$} & \multirow[t]{3}{*}{$1 / 300.000$} & \multirow[t]{3}{*}{601410} & \multirow[t]{3}{*}{ 6q24: PLAGL1: alt-TSS } & upd(6)pat & $40 \%$ & & & $<1 \%$ & \multirow{4}{*}{$\begin{array}{l}\text { IUGR, transient diabetes, } \\
\text { hyperglycemia without } \\
\text { ketoacidosis, macroglossia, } \\
\text { omphalocele }\end{array}$} \\
\hline & & & & paternal duplications & $40 \%$ & & No & Up to $50 \%$ & \\
\hline & & & & methylation defects & $20 \%$ & $\sim 50 \%$ & Yes & $<1 \%$ & \\
\hline Upd(6)mat & Unknown & & $\begin{array}{l}\text { Chromosome 6, } \\
\text { 6q16.1qter }\end{array}$ & upd(6)mat & & & Yes & Unknown & \\
\hline \multirow{7}{*}{$\begin{array}{l}\text { Silver-Russell syndrome } \\
\text { (SRS; Russell-Silver } \\
\text { Syndrome, RSS) }\end{array}$} & \multirow[t]{7}{*}{$\begin{array}{l}1 / 75.000- \\
1 / 100.000\end{array}$} & \multirow[t]{7}{*}{180860} & 7 & upd(7)mat & $\sim 10 \%$ & \multirow[t]{4}{*}{ case $^{a}$} & No & $<1 \%$ & \multirow{7}{*}{$\begin{array}{l}\text { IUGR/PNGR, small prematurely } \\
\text { calcified placenta, rel. macrocephaly } \\
\text { at birth, hemihypotrophy, prominent } \\
\text { forehead, triangular face, feeding } \\
\text { difficulties }\end{array}$} \\
\hline & & & \multirow[t]{3}{*}{ 11p15: } & upd(11p15)mat & single case & & Unknown & Rare & \\
\hline & & & & $\begin{array}{l}\text { Genome-wide uniparental } \\
\text { diploidy }\end{array}$ & single case & & Yes & Rare & \\
\hline & & & & maternal duplication & $<1 \%$ & & No & Up to $50 \%$ & \\
\hline & & & H19/IGF2: IG DMR & hypomethylation & $>38 \%^{a}$ & $\begin{array}{l}7- \\
10 \%\end{array}$ & Yes & $<1 \%$ & \\
\hline & & & CDKN1C & point mutations & 1 family reported & & No & $\begin{array}{l}\text { In familial cases: up } \\
\text { to } 50 \% \text { in case of } \\
\text { maternal transmission }\end{array}$ & \\
\hline & & & IGF2 & point mutations & 1 family reported & & No & & \\
\hline \multirow{6}{*}{$\begin{array}{l}\text { Beckwith-Wiedemann } \\
\text { syndrome (BWS; } \\
\text { Wiedemann-Beckwith } \\
\text { syndrome, EMG) }\end{array}$} & \multirow[t]{6}{*}{$1 / 15.000$} & \multirow[t]{6}{*}{130650} & 11p15: & upd(11p15)pat & $\sim 20 \%$ & & Yes & $<1 \%$ & \multirow{6}{*}{$\begin{array}{l}\text { Pre- and postnatal overgrowth, } \\
\text { organomegaly, macroglossia, } \\
\text { omphalocele, neonatal } \\
\text { hypoglycemia, hemihypertrophy, } \\
\text { increased tumour risk }\end{array}$} \\
\hline & & & & $\begin{array}{l}\text { Genome-wide uniparental } \\
\text { diploidy }\end{array}$ & $\sim 2 \%$ & & Yes & $<1 \%$ & \\
\hline & & & & chromosomal aberrations & $2-4 \%$ & & No & Up to $50 \%$ & \\
\hline & & & $\begin{array}{l}\text { IH19/IGF2: } \\
\text { IG DMR; KCNQ1OT1: } \\
\text { TSS-DMR }\end{array}$ & hypermethylation & $5-10 \%$ & & Yes & unclear & \\
\hline & & & & hypomethylation & $40-50 \%$ & $25 \%$ & Yes & $<1 \%$ & \\
\hline & & & CDKN1C & point mutations & $\begin{array}{l}5 \% \text { (sporadic) } \\
40-50 \% \text { (families) }\end{array}$ & & No & Up to $50 \%$ & \\
\hline \multirow{3}{*}{$\begin{array}{l}\text { Kagami-Ogata syndrome } \\
\text { (KOS14; upd(14)pat } \\
\text { syndrome) }\end{array}$} & \multirow[t]{3}{*}{ unknown } & \multirow[t]{3}{*}{608149} & 14q32: & upd(14)pat & $65 \%$ & & & in case of RT & \multirow{3}{*}{$\begin{array}{l}\text { IUGR, polyhydramnion, abdominal } \\
\text { and thoracal wall defects, bell- } \\
\text { shaped thorax, coat-hanger ribs }\end{array}$} \\
\hline & & & MEG3/DLK1: IG DMR & maternal deletion & $15 \%$ & & & up to $50 \%$ & \\
\hline & & & MEG3: TSS DMR & aberrant methylation & $20 \%$ & & & $<1 \%$ & \\
\hline \multirow{3}{*}{$\begin{array}{l}\text { Temple syndrome (TS14; } \\
\text { upd(14)mat syndrome) }\end{array}$} & \multirow[t]{3}{*}{ unknown } & \multirow[t]{3}{*}{616222} & 14q32: & upd(14)mat & $78 \%$ & & & In case of RT & \multirow{3}{*}{$\begin{array}{l}\text { IUGR/PNGR, neonatal hypotonia, } \\
\text { feeding difficulties in infancy, truncal } \\
\text { obesity, scoliosis, precocious puberty, } \\
\text { small feed and hands }\end{array}$} \\
\hline & & & MEG3/DLK1: IG DMR & paternal deletion & $10 \%$ & & & Up to $50 \%$ & \\
\hline & & & MEG3: TSS DMR & aberrant methylation & $12 \%$ & $\begin{array}{l}1 \\
\text { case }^{a}\end{array}$ & & $<1 \%$ & \\
\hline \multirow{2}{*}{$\begin{array}{l}\text { Prader-Willi syndrome } \\
\text { (PWS) }\end{array}$} & \multirow{2}{*}{$\begin{array}{l}1 / 25.000- \\
1 / 10.000\end{array}$} & \multirow[t]{2}{*}{176270} & \multirow[t]{2}{*}{$15 q 11-q 13$} & paternal deletion & $70 \%$ & & & Up to $50 \%$ & \multirow{2}{*}{$\begin{array}{l}\text { PNGR, mental retardation, neonatal } \\
\text { hypotonia, hypogenitalism, }\end{array}$} \\
\hline & & & & upd(15)mat & $<30 \%$ & & & In case of RT & \\
\hline
\end{tabular}


Table 1 Overview on the molecular findings in the currently known IDs and their clinical characteristics (Continued)

\begin{tabular}{|c|c|c|c|c|c|c|c|c|c|}
\hline & & & & aberrant methylation & $\sim 1 \%$ & 1 case & & $<1 \%$ & $\begin{array}{l}\text { hypopigmentation, obesity/ } \\
\text { hyperphagia }\end{array}$ \\
\hline \multirow{4}{*}{$\begin{array}{l}\text { Angelman syndrome } \\
\text { (AS) }\end{array}$} & \multirow{4}{*}{$\begin{array}{l}1 / 20.000- \\
1 / 12.000\end{array}$} & \multirow[t]{4}{*}{105830} & \multirow[t]{3}{*}{ 15q11-q13: } & maternal deletion & $70 \%$ & & No & Up to $50 \%$ & \multirow{4}{*}{$\begin{array}{l}\text { mental retardation, microcephaly, } \\
\text { no speech, unmotivated laughing, } \\
\text { ataxia, seizures, scoliosis }\end{array}$} \\
\hline & & & & upd(15)pat & $1-3 \%$ & & & In case of RT & \\
\hline & & & & aberrant methylation & $\sim 4 \%$ & & Yes & $<1 \%$ & \\
\hline & & & UBE3A & point mutations & $10-15 \%$ & & No & $\begin{array}{l}\text { In familial cases: up } \\
\text { to } 50 \% \text { in case of } \\
\text { maternal transmission }\end{array}$ & \\
\hline $\begin{array}{l}\text { Precocious puberty } \\
\text { (central precocious } \\
\text { puberty 2; cppb2) }\end{array}$ & Unknown & 614356 & 15q11.2: MKRN3 & point mutations & $100 \%$ & & No & $\begin{array}{l}\text { In familial cases: up } \\
\text { to } 50 \% \text { in case of } \\
\text { paternal transmission }\end{array}$ & $\begin{array}{l}\text { Early activation of the hypothalamic- } \\
\text { pituitary-gonadal axis results in } \\
\text { gonadotropin-dependent precocious } \\
\text { puberty }\end{array}$ \\
\hline Upd(16)mat & Unknown & & Chromosome 16 & $\begin{array}{l}\text { upd(16)mat, often } \\
\text { associated with } \\
\text { chromosomal aberrations }\end{array}$ & & & Yes & $<1 \%$ & $\begin{array}{l}\text { IUGR (40-85\%); heterogeneous, but } \\
\text { no specific or unique symptoms }\end{array}$ \\
\hline \multirow[t]{4}{*}{$\begin{array}{l}\text { Pseudohypo- } \\
\text { parathyroidism (PHP1B, } \\
\text { PHP1C, PHP1A) }\end{array}$} & \multirow[t]{4}{*}{ unknown } & 603233 & 20913: & $\begin{array}{l}\text { Maternally inherited } \\
\text { deletions causing } \\
\text { aberrant methylation }\end{array}$ & $8.5 \%$ & & & $\begin{array}{l}\text { Up to } 50 \% \text { in case of } \\
\text { maternal transmission }\end{array}$ & \multirow{4}{*}{$\begin{array}{l}\text { Resistance to PTH and other } \\
\text { hormones; Albright hereditary } \\
\text { osteodystrophy, subcutaneous } \\
\text { ossifications, feeding behaviour } \\
\text { anomalies, abnormal growth } \\
\text { patterns }\end{array}$} \\
\hline & & 612462 & \multirow[t]{3}{*}{ GNAS } & isolated epimutations & $42.5 \%$ & $12.5 \%$ & & $<1 \%$ & \\
\hline & & 103580 & & upd(20)pat & $2.5 \%$ & $12.5 \%$ & & $<1 \%$ & \\
\hline & & & & $\begin{array}{l}\text { maternal and paternal } \\
\text { heterozygous loss of } \\
\text { function mutations in } \\
\text { GNAS coding sequence }\end{array}$ & $46.5 \%$ & & No & $\begin{array}{l}\text { Up to } 50 \% \text { in case of } \\
\text { maternal transmission }\end{array}$ & \\
\hline Upd(20)mat syndrome & unknown & & Chromosome 20 & upd(20)mat & & & No & $<1 \%$ & IUGR, PNGR, feeding difficulties \\
\hline
\end{tabular}

IUGR intrauterine growth retardation, PNGR postnatal growth retardation

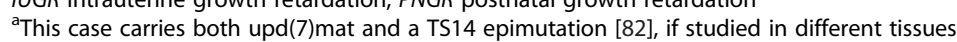


Table 2 Comparison of the major clinical findings in the known and suggested IDs, showing a broad clinical overlap between the different disorders

\begin{tabular}{|c|c|c|c|c|c|c|c|c|c|c|c|c|c|}
\hline Congenital ID & TNDM & upd(6)mat & SRS & & BWS & TS14 & KOS14 & PWS & AS & $\begin{array}{l}\text { Precocious } \\
\text { puberty }\end{array}$ & upd(16)mat & PHP & upd(20)mat \\
\hline Reference & {$[18]$} & $W_{e b}^{a}$ & [83] & & [33] & [43] & {$[84]$} & [52] & [85] & [61] & Web $^{a}$ & [86] & [70] \\
\hline $\begin{array}{l}\text { number of } \\
\text { patients }\end{array}$ & 155 & 13 & 20 & 44 & 403 & 51 & 34 & 90 & & & 61 & 63 & 15 \\
\hline $\begin{array}{l}\text { ID specific } \\
\text { chromosome }\end{array}$ & 6 & 6 & 7 & 11 & 11 & 14 & 14 & 15 & 15 & 15 & 16 & 20 & 20 \\
\hline \multirow[t]{2}{*}{$\begin{array}{l}\text { clinical } \\
\text { overlapwith }\end{array}$} & BWS & SRS & \multicolumn{2}{|l|}{$\begin{array}{l}\text { upd(6)mat, TS14, } \\
\text { upd(16)mat, } \\
\text { upd(20)mat }\end{array}$} & TNDM, KOS14 & SRS, PWS & BWS & TS14 & AS infant & & $\begin{array}{l}\text { SRS, } \\
\text { upd(6)mat, } \\
\text { upd(20)mat }\end{array}$ & & $\begin{array}{l}\text { SRS, } \\
\text { upd(6)mat, } \\
\text { upd(16)mat }\end{array}$ \\
\hline & \multicolumn{2}{|c|}{$\begin{array}{l}\text { Major clinical } \\
\text { and overlapping } \\
\text { findings }\end{array}$} & & & & & & & & & & & \\
\hline IUGR & Yes & $53.8 \%(7 / 13)$ & $70 \%$ & $82 \%$ & & $87 \%$ & 1 & Rare & No & & $77 \%(47 / 61)$ & & $100 \%$ \\
\hline $\begin{array}{l}\text { prenatal } \\
\text { overgrowth }\end{array}$ & & & & & Yes & & $58.8 \%(20 / 34)$ & & No & & & Yes & \\
\hline placenta & & & Abnormality: $8 \%$ & Abnormality: $35 \%$ & Placentomegaly & & Placentomegaly & & No & & & & \\
\hline polyhydramion & & & & & Reported & & $97 \%(33 / 34)$ & & No & & & & \\
\hline PNGR & Yes & $33.3 \%(2 / 6)$ & $65 \%$ & $57 \%$ & & $79 \%$ & $36.6 \%(11 / 30)$ & $63 \%$ & No & & $2 \%(1 / 49)$ & & $100 \%$ \\
\hline overgrowth & & & & & Yes & & $(6.7 \%(2 / 30)$ & & No & & & & \\
\hline organomegaly & & & & & $43.8 \%(153 / 349)$ & & & & No & & & & \\
\hline Asymmetry & & & $30 \%$ & $68 \%$ & $33.3 \%(126 / 378$ & $4 \%$ & & & No & & & & \\
\hline macroglossia & $44 \%(54 / 123)$ & & & & $94 \%(379 / 403)$ & & & & No & & & $\begin{array}{l}7 \% \\
(3 / 35)\end{array}$ & \\
\hline $\begin{array}{l}\text { relative } \\
\text { macrocephaly }\end{array}$ & & & $90 \%$ & $70 \%$ & & $56 \%$ & & & No & & & & 1 case \\
\hline $\begin{array}{l}\text { relative } \\
\text { microcephaly }\end{array}$ & & 1 case & & & & & & & $>80 \%$ & & & & \\
\hline hypotonia & & & $45 \%(n=143)$ & & & $93 \%$ & & $88 \%$ & $<80 \%$ & & & & 1 case \\
\hline \multirow[t]{2}{*}{$\begin{array}{l}\text { abdominal wall } \\
\text { defects }\end{array}$} & $21 \%(24 / 114)$ & 1 case & Rare & & $62.3 \%(250 / 401)$ & & $\begin{array}{l}\text { Omphalocele: } \\
32.3 \% \text { (11(34) }\end{array}$ & & No & & 1 case & & \\
\hline & & & & & $\begin{array}{l}\text { Exomphalos: } \\
56.8 \%(142 / 250)\end{array}$ & & $\begin{array}{l}\text { diastasis recti: } \\
67.6 \%(23 / 34)\end{array}$ & & & & & & \\
\hline $\begin{array}{l}\text { glycemic } \\
\text { disorder }\end{array}$ & TNDM: $100 \%$ & & $\begin{array}{l}\text { Hypoglycemia: } \\
24 \%\end{array}$ & $\begin{array}{l}\text { Hypoglycemia: } \\
19 \% \text {; diabetes } \\
\text { type } 2 \text { reported } \\
\text { in later life }\end{array}$ & $\begin{array}{l}\text { Hypoglycemia: } \\
43.4 \%(162 / 373)\end{array}$ & $\begin{array}{l}\text { Hypoglycemia } \\
\text { diabetes type } \\
2 \text { reported in } \\
\text { later life }\end{array}$ & & $\begin{array}{l}\text { Diabetes } \\
\text { type 2: } 25 \%\end{array}$ & no & & & & \\
\hline
\end{tabular}


Table 2 Comparison of the major clinical findings in the known and suggested IDs, showing a broad clinical overlap between the different disorders (Continued)

\begin{tabular}{|c|c|c|c|c|c|c|c|c|c|c|c|c|}
\hline $\begin{array}{l}\text { precocious } \\
\text { puberty }\end{array}$ & & Frequent & Frequent & Reported & $86 \%$ & & $4 \%[88]$ & No & $100 \%$ & & & \\
\hline $\begin{array}{l}\text { mental } \\
\text { retardation }\end{array}$ & & $\begin{array}{l}\text { Global delay: } \\
65 \%\end{array}$ & Global delay: $20 \%$ & & $39 \%$ & & $100 \%$ & $100 \%$ & & & $3 \%$ & \\
\hline speech delay & & $50 \%$ & $39 \%$ & & & & & $\begin{array}{l}\text { No } \\
\text { speech }\end{array}$ & & & & \\
\hline motor delay & & $50 \%(7 / 14)$ & $76 \%(26 / 34)$ & & & & & $100 \%$ & & & & \\
\hline $\begin{array}{l}\text { learning } \\
\text { difficulties }\end{array}$ & & & & & & & & $100 \%$ & & & $33 \%$ & \\
\hline behaviour & & $20 \%$ & $9 \%$ & & & & $70-90 \%$ & $100 \%$ & & & $9 \%$ & \\
\hline $\begin{array}{l}\text { feeding } \\
\text { difficulties }\end{array}$ & & $90 \%$ & $84 \%$ & Reported & $43 \%$ & & $78 \%$ & $>80 \%$ & & & & 7 cases \\
\hline seizures & 1 case & & & & & & & $>80 \%$ & & & & 1 case \\
\hline $\begin{array}{l}\text { excessive } \\
\text { sweating }\end{array}$ & & $75 \%$ & $64 \%$ & & & & & $\begin{array}{l}\text { Increased } \\
\text { sensitivity } \\
\text { to heat }\end{array}$ & & & & \\
\hline scoliosis & & $5 \%$ & $9 \%$ & & $23 \%$ & & $40-80 \%$ [88] & $<80 \%$ & & & & 1 case \\
\hline adipositas & & & $\begin{array}{l}\text { Reported in } \\
\text { later life [21] }\end{array}$ & & yes & & $67 \%$ & $<80 \%$ & & & & \\
\hline $\begin{array}{l}\text { dysmorphic/ } \\
\text { typical facial } \\
\text { gestalt }\end{array}$ & $18 \%(21 / 114)$ & Triangular face & & & & $100 \%$ & & $>80 \%$ & & $\begin{array}{l}14.2 \% \\
(6 / 49)\end{array}$ & & Mild \\
\hline $\begin{array}{l}\text { clinodactyly/ } \\
\text { finger } \\
\text { abnormalities }\end{array}$ & $8 \%(9 / 116)$ & $45 \%$ & $75 \%$ & & & & & & & & & 5 cases \\
\hline ear abnormalities & & $\begin{array}{l}\text { Low set } \\
\text { posterior }\end{array}$ & Low set posterior & $61.8 \%(230 / 372)$ & & & & & & & & \\
\hline otitis media & & $20 \%$ & $14 \%$ & & $17.6 \%(9 / 51)$ & & & & & & & \\
\hline hepatoblastoma & & & & Reported & & Reported & & & & & & \\
\hline $\begin{array}{l}\text { cardiac } \\
\text { anomalities }\end{array}$ & $9 \%(10 / 114)$ & & $9 \%$ & 5-10 \% [39] & & & & & & & & \\
\hline
\end{tabular}


and short stature are long known features of PHP1A, it became only recently apparent that growth and metabolism are affected in both paternal and maternal (epi)genetic alterations of the GNAS locus $[65,66]$.

\section{Do further imprinting disorders exist?}

Despite the gaps in understanding their pathoaetiology and their clinical heterogeneity, the aforementioned IDs are meanwhile well established as they are associated with molecular changes in disease-specific loci. However, three further clinical entities have been suggested in which imprinted genes are known or suspected to be involved, and which might become IDs.

\section{Maternal uniparental disomy of chromosome 6 (upd(6)mat)}

Maternal UPD of chromosome 6 (upd(6)mat) has been hypothesized to be associated with intrauterine growth retardation: among the 13 cases reported so far, 7 revealed a IUGR (http://www.fish.uniklinikum-jena.de/ UPD.html). Indeed, homozygosity of a recessive allele causing IUGR has been discussed as the pathogenic mechanism as many patients share an isodisomic region in 6q16qter. However, not all upd(6)mat carriers presenting IUGR share this region, in one case homozygosity of a recessive CUL7 has been identified causing $3 \mathrm{M}$ syndrome, a growth retardation syndrome. However, it has been postulated that upd(6)mat might be regarded as a further imprinting disorder [67].

\section{Maternal uniparental disomy of chromosome 16 (upd(16)mat)}

Maternal UPD of chromosome 16 (upd(16)mat) is the most often reported UPD other than upd(15). This is not surprising since risk of UPD is much higher in chromosomes involved in aneuploidies and trisomy 16 is the most common autosomal trisomy in human abortions. Trisomy 16 itself is usually lethal in non-mosaic state in the fetus, but in trisomy rescue is compatible with life. As a consequence of UPD formation by trisomy rescue, many of the reported upd(16)mat cases are associated with trisomy 16 mosaicism in the placenta (for review, http:// www.fish.uniklinikum-jena.de/UPD.html). The upd(16)mat has been suspected to have clinical consequences. However, the heterogeneity of the birth defects observed suggested that the phenotype might rather be influenced by placenta insufficiency than by the UPD itself [68]. The possibility that upd(16)mat is associated with imprinting is difficult to assess due to the trisomy 16 mosaicism present in many cases. By an extensive clinical analysis of a series of mosaic trisomy 16 cases $(\mathrm{n}=83)$ including $\operatorname{upd}(16)$ mat $(\mathrm{n}=33)$, Yong et al. [69] concluded that upd(16)mat might be associated with more severe growth retardation in utero and an elevated risk of malformation. However, the role of imprinted genes on chromosome 16 contributing to the phenotype is unclear at the moment.

\section{Maternal uniparental disomy of chromosome 20 (upd(20)mat)}

Maternal uniparental disomy of chromosome 20 (upd(20)mat) has been reported in 12 patients [70], 3 of whom also had mosaicism for complete or partial trisomy of chromosome 20. All patients with upd(20)mat had intrauterine and postnatal growth retardation, and prominent feeding difficulties with failure to thrive often requiring gastric tube feeding in the first few years of life. No dysmorphisms or congenital abnormalities or major developmental delay have been reported. So far, other types of molecular alterations have not yet been reported, and a candidate region on chromosome 20 has not yet been defined. It is striking that these patients have not been described to have features reminiscent of paternal GNAS loss of function mutations, although the loss of the paternal GNAS allele (on chromosome 20) is associated with pre- and postnatal growth defect and Albright hereditary osteodystrophy [8]. However, upd(20)mat probably presents a new imprinting disorder and its identification requires specialized molecular testing, which should be performed in patients with early-onset idiopathic isolated growth failure. In particular patients with a clinical diagnosis of SRS or TS14, but exclusion of their known molecular disturbances, are strong candidates for upd(20)mat as there appears to be significant phenotypic overlap.

\section{Multi-locus imprinting disturbances and the "imprinted gene network"}

The clinical and molecular overlap between IDs suggests that there may be causal links between them, either by shared causes of dysregulation affecting multiple imprinted genes, or by perturbation of interactions between the products of imprinted genes.

A growing number of ID patients have been reported to exhibit multilocus imprinting disturbance or MLID which can vary depending on the tissues studied [22, 71] (Table 1). Whilst the mechanisms associated with MLID are currently unknown, they all present with underlying aberrations in allelic DNA methylation. Indeed, evidence is growing that genomic mutations are involved in the etiology of MLID; known trans-acting factors include mutations in the ZFP57, the NLRP2 or the NLRP7 genes [72-75].

Another hypothesis which explains the clinical and molecular overlap between the different IDs is the "imprinted gene network" (IGN) [76]. The existence of the IGN has been based on the observation of coexpression of imprinted transcript, as recently reported 
for the imprinted transcription factor PLAGL1, the gene responsible for TNDM [77]. Changes in imprinted gene abundance occur due to increased transcription from the active allele in a DNA methylation independent fashion [78]. Recently, additional gene networks have been described including the role of unoccupied insulin (IR) and insulin-like growth factor 1 receptor (IGF1R) signalling in the coordinated regulation of multiple imprinted genes associated with growth and development in mouse [79]. Interestingly this regulation is independent of PLAGL1, despite this gene being downregulated by more than $80 \%$ in the IR and IGF1R double knockout cells.

Finally the paternally expressed non-coding RNA IPW located in the commonly deleted chromosome 15 region in PWS regulates the levels of maternally expressed transcripts within the imprinted cluster on chromosome 14 [80]. The transcriptional repression of the DLK1-DIO3 locus by $I P W$ is due to altered repressive histone modifications at the IG-DMR, which is independent of DNA methylation, via targeted recruitment of the histone methyltransferase G9a. These observations support the reports of affected individuals with TS14 who display PWS-like phenotypes [81], enforcing the view that phenotypes associated with some IDs may be caused by aberrant expression of imprinted genes within other imprinted loci.

\section{Conclusion}

Recent rapid advances in the molecular and clinical pathogenesis of IDs have vividly illustrated the complexity of imprinting regulation, its vulnerability to genetic and epigenetic disturbance and its power as a paradigm of the interplay between genetics, epigenetics and phenotype. Identification of new mutational and epimutational pathways offers the potential for more precise molecular diagnosis and the development of new therapeutic regimes as the basis for a more directed and personalised medicine in IDs. At the same time, study of IDs may have impact beyond the borders of rare disorders, since they offer clear and tractable paradigms of the interplay between genetic, epigenetic and environmental variation upon human disorders spanning disturbances of growth and metabolism, diabetes and cancer.

\section{Competing interest}

The authors declare that there are no competing interests.

\begin{abstract}
Authors' contributions
TE prepared the draft. All authors approved the content and contributed their expertise in the different fields of imprinting disorders, i.e. TE, DM and IN in the field of Silver-Russell syndrome, ZT and KG for chromosome 15 disorders, AR, IN and ERM for Beckwith-Wiedemann syndrome, IKT and DJM for chromosome 14 syndromes and TNDM, AL and GPN for PHP. ZT and TE developed the figures. All authors read and approved the final manuscript.
\end{abstract}

\section{Acknowledgements}

All authors are members of the EUCID.net network, funded by COST (BM1208). TE is funded by the German Ministry of research and education (01GM1513B). GPdN is funded by I3SNS Program of the Spanish Ministry of
Health (CP03/0064; SIVI 1395/09), Instituto de Salud Carlos III (PI13/00467) and Basque Department of Health (GV2014/111017).

\section{Author details}

'Department of Human Genetics, RWTH Aachen, Pauwelsstr. 30, Aachen, Germany. ${ }^{2}$ Molecular (Epi)Genetics Laboratory, BioAraba National Health Institute, Hospital Universitario Araba, Vitoria-Gasteiz, Spain. ${ }^{3}$ Department of Medical Genetics, University of Cambridge and NIHR Cambridge Biomedical Research Centre, Cambridge, UK. ${ }^{4}$ Human Genetics and Genomic Medicine, Faculty of Medicine University of Southampton, Southampton, UK. ${ }^{5}$ Wessex Clinical Genetics Service, Princess Anne Hospital, Coxford Road,

Southampton, UK. ${ }^{6}$ Clinical Genetic Clinic, Kennedy Center, Rigshospitalet, Copenhagen University Hospital, Glostrup, Denmark. ${ }^{7}$ Imprinting and Cancer Group, Cancer Epigenetic and Biology Program (PEBC), Institut d'Investigació Biomedica de Bellvitge (IDIBELL), Hospital Duran i Reynals, Barcelona, Spain. ${ }^{8}$ DiSTABiF, Seconda Università degli Studi di Napoli, Caserta, Italy. Institute of Genetics and Biophysics-ABT, CNR, Napoli, Italy. ${ }^{10}$ Endocrinology and diabetology for children and reference center for rare disorders of calcium and phosphorus metabolism, Bicêtre Paris Sud, APHP, Le Kremlin-Bicêtre, France. ${ }^{11}$ INSERM U986, INSERM, Le Kremlin-Bicêtre, France. ${ }^{12}$ INSERM, UMR_S 938, CDR Saint-Antoine, Paris F-75012, France. ${ }^{13}$ Sorbonne Universites, UPMC Univ Paris 06, UMR_S 938, CDR Saint-Antoine, Paris, France. ${ }^{14} 3$ APHP, Pediatric Endocrinology, Armand Trousseau Hospital, Paris, France.

Received: 14 July 2015 Accepted: 29 September 2015

Published online: 14 November 2015

\section{References}

1. Hanna CW, Kelsey G. The specification of imprints in mammals. Heredity (Edinb). 2014;113:176-83.

2. Kalish JM, Conlin LK, Bhatti TR, Dubbs HA, Harris MC, Izumi K, et al. Clinical features of three girls with mosaic genome-wide paternal uniparental isodisomy. Am J Med Genet A. 2013;161:1929-39.

3. Eggermann T, Soellner L, Buiting K, Kotzot D. Mosaicism and uniparental disomy in prenatal diagnosis. Trends Mol Med. 2015;21:77-87.

4. Shaffer LG, Agan N, Goldberg JD, Ledbetter DH, Longshore JW, Cassidy SB. American college of medical genetics statement on diagnostic testing for uniparental disomy. Genet Med. 2001;3:206-11.

5. Abi Habib W, Azzi S, Brioude F, Steunou V, Thibaud N, Das Neves C, et al, Extensive investigation of the IGF2/H19 imprinting control region reveals novel OCT4/SOX2 binding site defects associated with specific methylation patterns in Beckwith-Wiedemann syndrome. Hum Mol Genet. 2014;23:5763-73.

6. De Crescenzo A, Sparago A, Cerrato F, Palumbo O, Carella M, Miceli M, et al. Paternal deletion of the 11 p15.5 centromeric-imprinting control region is associated with alteration of imprinted gene expression and recurrent severe intrauterine growth restriction. J Med Genet. 2013;50:99-103.

7. Cerrato F, De Crescenzo A, Riccio A. Looking for CDKN1C enhancers. Eur J Hum Genet. 2014;22:442-3.

8. Linglart A, Maupetit-Méhouas S, Silve C. GNAS -related loss-of-function disorders and the role of imprinting. Horm Res Paediatr. 2013;29:119-29.

9. Brioude F, Oliver-Petit I, Blaise A, Praz F, Rossignol S, Le Jule M, et al. CDKN1C mutation affecting the PCNA-binding domain as a cause of familial Russell Silver syndrome. J Med Genet. 2013;50:823-30.

10. Grønskov K, Poole RL, Hahnemann JM, Thomson J, Tümer Z, BrøndumNielsen $\mathrm{K}$, et al. Deletions and rearrangements of the H19/IGF2 enhancer region in patients with Silver-Russell syndrome and growth retardation. J Med Genet. 2011;48:308-11.

11. Kagami M, O'Sullivan MJ, Green AJ, Watabe Y, Arisaka O, Masawa N, et al. The IG-DMR and the MEG3-DMR at human chromosome 14q32.2: hierarchical interaction and distinct functional properties as imprinting control centers. PLoS Genet. 2010;6:e1000992.

12. Horsthemke B. Epimutations in human disease. Curr Top Microbiol Immunol. 2006;310:45-59.

13. Uyar A, Seli E. The impact of assisted reproductive technologies on genomic imprinting and imprinting disorders. Curr Opin Obstet Gynecol. 2014;26:210-21.

14. Beygo J, Citro V, Sparago A, De Crescenzo A, Cerrato F, Heitmann M, et al. The molecular function and clinical phenotype of partial deletions of the IGF2/H19 imprinting control region depends on the spatial arrangement of the remaining CTCF-binding sites. Hum Mol Genet. 2013;22:544-57. 
15. Bestor TH. Imprinting errors and developmental asymmetry. Philos Trans R Soc Lond B Biol Sci. 2003;358:1411-5.

16. Temple IK, Shield JP. 6 q24 transient neonatal diabetes. Rev Endocr Metab Disord. 2010:11:199-204.

17. Mackay D, Bens S, Perez de Nanclares G, Siebert R, Temple IK. Clinical utility gene card for: Transient Neonatal Diabetes Mellitus, 6q24-related. Eur J Hum Genet. 2014. doi:10.1038/ejhg.2014.27.

18. Docherty LE, Kabwama S, Lehmann A, Hawke E, Harrison L, Flanagan SE, et al. Clinical presentation of $6 \mathrm{q} 24$ transient neonatal diabetes mellitus (6q24 TNDM) and genotype-phenotype correlation in an international cohort of patients. Diabetologia. 2013;56:758-62.

19. Boonen SE, Mackay DJ, Hahnemann JM, Docherty L, Grønskov K, Lehmann A, et al. Transient neonatal diabetes, ZFP57 and hypomethylation of multiple imprinted loci: a detailed follow-up. Diabetes Care. 2013;36:505-12.

20. Gardner RJ, Mackay DJG, Mungall AJ, Polychronakos C, Siebert R, Shield JP, et al. An imprinted locus associated with transient neonatal diabetes mellitus. Hum Mol Genet. 2000;9:589-96.

21. Takenouchi T, Awazu M, Eggermann T, Kosaki K. Adult phenotype of russellsilver syndrome: a molecular support for Barker-Brenner's theory. Congenit Anom. 2015. doi:10.1111/cga.12105 [Epub ahead of print].

22. Azzi S, Blaise A, Steunou V, Harbison MD, Salem J, Brioude F, et al. Complex tissue-specific epigenotypes in Russell-Silver Syndrome associated with 11 15 ICR1 hypomethylation. Hum Mutat. 2014;35:1211-20.

23. Azzi S, Salem J, Thibaud N, Chantot-Bastaraud S, Lieber E, Netchine I, et al. A prospective study validating a clinical scoring system and demonstrating phenotypical-genotypical correlations in Silver-Russell syndrome. J Med Genet. 2015;52(7):446-53.

24. Abu-Amero S, Monk D, Frost J, Preece M, Stanier P, Moore GE. The genetic aetiology of Silver-Russell syndrome. J Med Genet. 2008;45:193-9.

25. Netchine I, Rossignol S, Dufourg MN, Azzi S, Rousseau A, Perin L, et al. 11 p15 imprinting center region 1 loss of methylation is a common and specific cause of typical Russell-Silver syndrome: clinical scoring system and epigeneticphenotypic correlations. J Clin Endocrinol Metab. 2007;92:3148-54

26. Bruce S, Hannula-Jouppi K, Puoskari M, Fransson I, Simola KO, LipsanenNyman M, et al. Submicroscopic genomic alterations in Silver-Russell syndrome and Silver-Russell-like patients. J Med Genet. 2010;47:816-22.

27. Spengler S, Begemann M, Ortiz Brüchle N, Baudis M, Denecke B, Kroisel PM, et al. Molecular karyotyping as a relevant diagnostic tool in children with growth retardation with Silver-Russell features. J Pediatr. 2012;161:933-42.

28. Gicquel C, Rossignol S, Cabrol S, Houang M, Steunou V, Barbu V, et al. Epimutation of the telomeric imprinting center region on chromosome 11 p15 in Silver-Russell syndrome. Nat Genet. 2005;37:1003-7.

29. Eggermann T, Spengler S, Begemann M, Binder G, Buiting K, Albrecht B, et al. Deletion of the paternal allele of the imprinted MEST/PEG1 region in a patient with Silver-Russell syndrome features. Clin Genet. 2012;81:298-300.

30. Begemann M, Zirn B, Santen G, Wirthgen E, Soellner L, Büttel HM, Schweizer $R$, van Workum W, Binder G, Eggermann T. Paternally inherited IGF2 mutation and growth restriction. N Engl J Med. 2015. [Epub ahead of print].

31. Cooper WN, Luharia A, Evans GA, Raza H, Haire AC, Grundy R, et al. Molecular subtypes and phenotypic expression of Beckwith-Wiedemann syndrome. Eur J Hum Genet. 2005;13:1025-32.

32. Choufani S, Shuman C, Weksberg R. Beckwith-Wiedemann syndrome. Am J Med Genet. 2010;154C:343-54.

33. Brioude F, Lacoste A, Netchine I, Vazquez MP, Auber F, Audry G, et al. Beckwith-Wiedemann syndrome: growth pattern and tumor risk according to molecular mechanism, and guidelines for tumor surveillance. Horm Res Paediatr. 2013:80:457-65

34. Shuman C, Beckwith JB, Smith AC, et al. Beckwith-Wiedemann Syndrome. 2000 Mar 3 [Updated 2010 Dec 14]. In: Pagon RA, Adam MP, Ardinger HH et al., editors. GeneReviews ${ }^{\oplus}$ [Internet]. Seattle (WA): University of Washington, Seattle; 1993-2015. Available from: http:// www.ncbi.n/m.nih.gov/books/NBK1394/

35. Sparago A, Cerrato F, Vernucci M, Ferrero GB, Silengo MC, Riccio A Microdeletions in the human H19 DMR result in loss of IGF2 imprinting and Beckwith-Wiedemann syndrome. Nat Genet. 2004;36:958-60.

36. Demars J, Shmela ME, Rossignol S, Okabe J, Netchine I, Azzi S, et al. Analysis of the IGF2/H19 imprinting control region uncovers new genetic defects, including mutations of OCT-binding sequences, in patients with 11 p15 fetal growth disorders. Hum Mol Genet. 2010;19:803-14.

37. Brioude F, Netchine I, Praz F, Jule ML, Calmel C, Lacombe D, et al. Mutations of the imprinted CDKN1C gene as a cause of the overgrowth Beckwith
Wiedemann syndrome: clinical spectrum and functional characterization. Hum Mutat. 2015. doi:10.1002/humu.22824.

38. Tee L, Lim DH, Dias RP, Baudement MO, Slater AA, Kirby G, et al. Epimutation profiling in Beckwith-Wiedemann syndrome: relationship with assisted reproductive technology. Clin Epigenetics. 2013;5:23.

39. Ibrahim A, Kirby G, Hardy C, Dias RP, Tee L, Lim D, et al. Methylation analysis and diagnostics of Beckwith-Wiedemann syndrome in 1,000 subjects. Clin Epigenetics. 2014;6:11.

40. Mussa A, Russo S, De Crescenzo A, Freschi A, Calzari L, Maitz S, et al. (Epi)genotype-phenotype correlations in Beckwith-Wiedemann syndrome. Eur J Hum Genet. 2015. doi:10.1038/ejhg.2015.88.

41. Temple IK, Cockwell A, Hassold T, Pettay D, Jacobs P. Maternal uniparental disomy for chromosome 14. J Med Genet. 1991;28:511-4.

42. Kagami M, Sekita Y, Nishimura G, Irie M, Kato F, Okada M, et al. Deletions and epimutations affecting the human chromosome $14 \mathrm{q} 32.2$ imprinted region in individuals with paternal and maternal upd(14)-like phenotypes. Nat Genet. 2008:40:237-42

43. Ioannides Y, Lokulo-Sodipe K, Mackay DJ, Davies JH, Temple IK. Temple syndrome: improving the recognition of an underdiagnosed chromosome 14 imprinting disorder: an analysis of 51 published cases. J Med Genet. 2014:51:495-501.

44. Eggermann T, Netchine I, Temple IK, Tümer Z, Monk D, Mackay D, et al. Congenital imprinting disorders: EUCID.net - a network to decipher their aetiology and to improve the diagnostic and clinical care. Clin Epigenetics. 2015;7:23.

45. Kagami M, Kurosawa K, Miyazaki O, Ishino F, Matsuoka K, Ogata T. Comprehensive clinical studies in 34 patients with molecularly defined UPD(14)pat and related conditions (Kagami-Ogata syndrome). Eur J Hum Genet. 2015. doi:10.1038/ejhg.2015.13.

46. Beygo J, Elbracht M, de Groot K, Begemann M, Kanber D, Platzer K, et al Novel deletions affecting the MEG3-DMR provide further evidence for a hierarchical regulation of imprinting in 14q32. Eur J Hum Genet. 2015;23:180-8

47. Tan WH, Bacino CA, Skinner SA, Anselm I, Barbieri-Welge R, Bauer-Carlin A et al. Angelman syndrome: mutations influence features in early childhood. Am J Med Genet A. 2011:155:81-90.

48. Buiting K, Barnicoat A, Lich C, Pembrey M, Malcolm S, Horsthemke B. Disruption of the bipartite imprinting center in a family with Angelman syndrome. Am J Hum Genet. 2001;68:1290-4.

49. Buiting K, Gross S, Lich C, Gillessen-Kaesbach G, el-Maarri O, Horsthemke B. Epimutations in Prader-Willi and Angelman syndromes: a molecular study of 136 patients with an imprinting defect. Am J Hum Genet. 2003;72:571-7.

50. Rougeulle C, Glatt H, Lalande M. The Angelman syndrome candidate gene, UBE3A/E6-AP, is imprinted in brain. Nat Genet. 1997;17:14-5

51. $\mathrm{Vu}$ TH, Hoffman AR. Imprinting of the Angelman syndrome gene, UBE3A, is restricted to brain. Nat Genet. 1997;17:12-3.

52. Holm VA, Cassidy SB, Butler MG, Hanchett JM, Greenswag LR, Whitman BY, et al. Prader-Willi syndrome: consensus diagnostic criteria. Pediatrics. 1993;91:398-402.

53. Gunay-Aygun M, Schwartz S, Heeger S, O'Riordan MA, Cassidy SB. The changing purpose of Prader-Willi syndrome clinical diagnostic criteria and proposed revised criteria. Pediatrics. 2001;108:E92.

54. Buiting K, Saitoh S, Gross S, Dittrich B, Schwartz S, Nicholls RD, et al. Inherited microdeletions in the Angelman and Prader-Willi syndromes define an imprinting centre on human chromosome 15. Nat Genet. 1995:9:395-400.

55. Sahoo T, del Gaudio D, German JR, Shinawi M, Peters SU, Person RE, et al. Prader-Willi phenotype caused by paternal deficiency for the HBII-85 C/D box small nucleolar RNA cluster. Nat Genet. 2008;40:719-21.

56. de Smith AJ, Purmann C, Walters RG, Ellis RJ, Holder SE, Van Haelst MM, et al. A deletion of the HBII-85 class of small nucleolar RNAs (snoRNAs) is associated with hyperphagia, obesity and hypogonadism. Hum Mol Genet. 2009;18:3257-65.

57. Abreu AP, Dauber A, Macedo DB, Noel SD, Brito VN, Gill JC, et al. Central precocious puberty caused by mutations in the imprinted gene MKRN3. N Engl J Med. 2013:368:2467-75.

58. de Vries L, Gat-Yablonski G, Dror N, Singer A, Phillip M. A novel MKRN3 missense mutation causing familial precocious puberty. Hum Reprod. 2014;29:2838-43

59. Schreiner F, Gohlke B, Hamm M, Korsch E, Woelfle J. MKRN3 mutations in familial central precocious puberty. Horm Res Paediatr. 2014;82:122-6. 
60. Settas N, Dacou-Voutetakis C, Karantza M, Kanaka-Gantenbein C, Chrousos GP, Voutetakis A. Central precocious puberty in a girl and early puberty in her brother caused by a novel mutation in the MKRN3 gene. J Clin Endocrinol Metab. 2014;99:E647-51.

61. Macedo DB, Abreu AP, Reis AC, Montenegro LR, Dauber A, Beneduzzi D. Central precocious puberty that appears to be sporadic caused by paternally inherited mutations in the imprinted gene makorin ring finger 3 . J Clin Endocrinol Metab. 2014:99:E1097-103.

62. Linglart A, Bastepe $M$, Jüppner $H$. Similar clinical and laboratory findings in patients with symptomatic autosomal dominant and sporadic pseudohypoparathyroidism type lb despite different epigenetic changes at the GNAS locus. Clin Endocrinol. 2007:67:822-31.

63. de Nanclares GP, Fernández-Rebollo E, Santin I, García-Cuartero B, Gaztambide S, Menéndez E, et al. Epigenetic defects of GNAS in patients with pseudohypoparathyroidism and mild features of Albright's hereditary osteodystrophy. J Clin Endocrinol Metab. 2007:96:2370-3.

64. Mantovani G. Clinical review: Pseudohypoparathyroidism: diagnosis and treatment. J Clin Endocrinol Metab. 2011;96:3020-30.

65. Richard N, Molin A, Coudray N, Rault-Guillaume P, Juppner H, Kottler ML. Paternal GNAS mutations lead to severe intrauterine growth retardation (IUGR) and provide evidence for a role of XLalphas in fetal development. J Clin Endocrinol Metab. 2013;98:E1549-56.

66. Brehin AC, Colson C, Maupetit-Mehouas S, Grybek V, Richard N, Linglart A, et al. Loss of methylation at GNAS exon A/B is associated with increased intrauterine growth. J Clin Endocrinol Metab. 2015;100:E623-31.

67. Poke G, Doody M, Prado J, Gattas M. Segmental maternal UPD6 with prenatal growth restriction. Mol Syndromol. 2013;3:270-3.

68. Ledbetter DH, Engel E. Uniparental disomy in humans: development of an imprinting map and its implications for prenatal diagnosis. Hum Mol Genet. 1995;4:1757-64.

69. Yong PJ, Marion SA, Barrett IJ, Kalousek DK, Robinson WP. Evidence for imprinting on chromosome 16: the effect of uniparental disomy on the outcome of mosaic trisomy 16 pregnancies. Am J Med Genet. 2002;112:123-32.

70. Mulchandani S, Bhoj E, Luo M, Powell-Hamilton N, Jenny K, Gripp K, et al Maternal Uniparental Disomy of Chromosome 20: A Novel Imprinting Disorder of Growth Failure. Genet Med. in press.

71. Mackay DJ, Eggermann T, Buiting K, Garin I, Netchine I, Linglart A, et al. Multilocus methylation defects in imprinting disorders. Biomol Concepts. 2015;6:47-57.

72. Mackay DJ, Callaway JL, Marks SM, White HE, Acerini CL, Boonen SE, et al. Hypomethylation of multiple imprinted loci in individuals with transient neonatal diabetes is associated with mutations in ZFP57. Nat Genet. 2008:40:949-51.

73. Meyer E, Lim D, Pasha S, Tee LJ, Rahman F, Yates JR, et al. Germline mutation in NLRP2 (NALP2) in a familial imprinting disorder (BeckwithWiedemann Syndrome). PLoS Genet. 2009;5, e1000423.

74. Murdoch S, Mazhar B, Seoud M, Khan R, Kuick R, Bagga R, et al. Mutations in NALP7 cause recurrent hydatidiform moles and reproductive wastage in humans. Nat Genet. 2006;38:300-2.

75. Docherty LE, Rezwan Fl, Poole RL, Turner CL, Kivuva E, Maher ER, et al. Mutations in NLRP5 are associated with reproductive wastage and multilocus imprinting disorders in humans. Nat Commun. 2015;6:8086. doi:10.1038/ncomms9086.

76. Varrault A, Gueydan C, Bellmann A, Houssami S, Aknin C, Severac D, et al. Zac1 regulates an imprinted gene network critically involved in the control of embryonic growth. Dev Cell. 2006;11:711-22.

77. Al Adhami H, Evano B, Le Digarcher A, Gueydan C, Dubois E, et al. A systems-level approach to parental genomic imprinting: the imprinted gene network includes extracellular matrix genes and regulates cell cycle exit and differentiation. Genome Res. 2015;25:353-67.

78. Iglesias-Platas I, Martin-Trujillo A, Petazzi P, Guillaumet-Adkins A, Esteller M, Monk D. Altered expression of the imprinted transcription factor PLAGL1 deregulates a network of genes in the human IUGR placenta. Hum Mol Genet. 2014;23:6275-85.

79. Boucher J, Charalambous M, Zarse K, Mori MA, Kleinridders A, Ristow M, et al. Insulin and insulin-like growth factor 1 receptors are required for normal expression of imprinted genes. Proc Natl Acad Sci U S A. 2014;111:14512-7.
80. Stelzer Y, Sagi I, Yanuka O, Eiges R, Benvenisty N. The noncoding RNA IPW regulates the imprinted DLK1-DIO3 locus in an induced pluripotent stem cell model of Prader-Willi syndrome. Nat Genet. 2014;46:551-7.

81. Hosoki K, Kagami M, Tanaka T, Kubota M, Kurosawa K, Kato M, et al. Maternal uniparental disomy 14 syndrome demonstrates prader-willi syndrome-like phenotype. J Pediatr. 2009;155:900-3.

82. Begemann M, Spengler S, Kordass U, Schröder C, Eggermann T. Segmental maternal uniparental disomy 7q associated with DLK1/GTL2 (14q32) hypomethylation. Am J Med Genet A. 2012;158:423-8.

83. Wakeling EL, Amero SA, Alders M, Bliek J, Forsythe E, Kumar S, et al. Epigenotype-phenotype correlations in Silver-Russell syndrome. J Med Genet. 2010;47:760-8.

84. Kagami M, Kato F, Matsubara K, Sato T, Nishimura G, Ogata T. Relative frequency of underlying genetic causes for the development of UPD(14)pat-like phenotype. Eur J Hum Genet. 2012;20:928-32.

85. Bird LM. Angelman syndrome: a review of clinical and molecular aspects. Appl Clin Genet. 2014;7:93-104

86. Maupetit-Méhouas S, Azzi S, Steunou V, Sakakini N, Silve C, Reynes C, et al Simultaneous hyper- and hypomethylation at imprinted loci in a subset of patients with GNAS epimutations underlies a complex and different mechanism of multilocus methylation defect in pseudohypoparathyroidism type 1b. Hum Mutat. 2013;34:1172-80.

87. Wollmann HA, Kirchner T, Enders H, Preece MA, Ranke MB. Growth and symptoms in Silver-Russell syndrome: review on the basis of 386 patients. Eur J Pediatr. 1995;154:958-68.

88. Driscoll DJ, Miller JL, Schwartz S, et al. Prader-Willi Syndrome. 1998 Oct 6 [Updated 2014 Jan 23]. In: Pagon RA, Adam MP, Ardinger HH, et al., editors. GeneReviews $^{\circledast}$ [Internet]. Seattle (WA): University of Washington, Seattle; 1993-2015. Available from: http://www.ncbi.nlm.nih.gov/books/NBK1330/

\section{Submit your next manuscript to BioMed Central and take full advantage of:}

- Convenient online submission

- Thorough peer review

- No space constraints or color figure charges

- Immediate publication on acceptance

- Inclusion in PubMed, CAS, Scopus and Google Scholar

- Research which is freely available for redistribution 